Bol. Acad. peru. leng. 54. 2012 (13-61)

\title{
EL PADRE JERÓNIMO DIEGO CISNEROS, LOS LIBROS PROHIBIDOS Y EL MERCURIO PERUANO
}

\section{LE PRÊTRE JERÓNIMO DIEGO CISNEROS, LES LIVRES INERDITS ET LE MERCURIO PERUANO}

\section{THE HIERONYMITE FATHER DIEGO CISNEROS, THE FORBIDDEN BOOKS AND THE PERUVIAN PUBLICATION MERCURIO PERUANO}

\author{
F. Javier Campos y Fernández de Sevilla \\ Estudios Superiores del Escorial (España)
}

Resumen:

Fray Diego Cisneros fue monje jerónimo del Escorial y bibliotecario de su Librería Real. En 1772 marchó a Perú como administrador de las rentas de unas encomiendas donadas por Felipe IV al monasterio como pago de la fundación de sufragios creada por el monarca, y para gestionar todo lo relacionado con la administración de los libros litúrgicos del Nuevo Rezado. Por su amplia cultura y espíritu abierto, se conectó con el grupo de intelectuales de Lima y formó parte de la Sociedad de Amantes del País, editora del periódico Mercurio Peruano (1790-1795) que fue un importante proyecto ilustrado de la última década del setecientos.

\section{Résumé:}

Fray Diego Cisneros était moine Jeronimo de l'Escorial et bibliothécaire de sa Librairie Royale. En 1772 il est allé au Pérou comme administrateur 
des revenus des commissions octroyées par Felipe IV au monastère comme paiement de la fondation de suffrages crée par le monarque, et pour gérer tout ce qui était lié à l'administration des livres liturgiques del Nuevo Rezado. Dû sa vaste culture et son esprit ouvert a fait des contacts avec le groupe d'intellectuels de Lima et fait partie de la Société des Amants du Pays, éditrice du journal Mercurio Peruano (1790-1795) qui était un importante projet illustré de la dernière décennie des années sept cents.

\section{Abstract:}

Friar Diego Cisneros (1737-1812) was a Hieronymite monk at El Escorial and librarian at the Royal Spanish Library. In 1772 he went to Peru as auditor of the rents of some encomiendas granted by Philip IV of Spain to a monastery in payment for prayers, a system that the king himself had created, he was also in charge of the sale of liturgical books called Nuevo Rezado (New Forms of Prayer). For his broad cultural background and open mind he soon made contact with the intellectuals of Lima and became a member of the Society of True Patriots which edited a magazine called Mercurio Peruano (Peruvian Mercury) which was an important cultural project is the last decade of the eighteenth century.

Palabras claves: Diego Cisneros, monasterio del Escorial, Nuevo Rezado, Ilustración, Felipe IV, Sociedad de Amantes del País, Mercurio Peruano, encomiendas, Inquisición.

Mots clés: Diego Cisneros, monastère de l' Escorial, Nuevo Rezado, Illustration, Felipe IV, Société des Amants du Pays, Mercurio Peruano, commissions, Inquisition.

Key words: Diego Cisneros, El Escorial Monastery, New forms of prayer, enlightenment, Philip IV, Society of True Patriots, the Peruvian Mercury, lands of private ownership, the Inquisition. 
Fecha de recepción: $\quad$ 28/09/2012

Fecha de aceptación: $\quad$ 10/10/2012

\section{Introducción}

El padre jerónimo, como se le conoció popularmente en Lima y así consta en el nombre de la calle —hoy Jr. Puno (Gálvez 1943: 37, 38 y 39; Bromley 2005) - donde tuvo su casa y que en homenaje a su figura le dedicó la Municipalidad, fue un personaje clave en la vida cultural de la capital del virreinato como han resaltado los autores. Consultando fuentes españolas y peruanas hemos actualizado su figura, completando afirmaciones vagas y algunas lagunas ${ }^{1}$.

Nos proponemos aquí presentar un resumen de su actividad literaria teniendo en cuenta el carácter de la revista donde aparecerá este trabajo y el interés de los posibles lectores, aunque por las potencialidades de Internet podrá llegar a un público mucho mayor demostrando que la globalización de la cultura es un aspecto real mayor que el de la política y la economía.

Antes que nada creemos importante recoger la visión que se ha difundido del P. Cisneros en la bibliografía peruana. Aunque es citado en muchas obras relativas a la Ilustración en Lima y al Mercurio Peruano, la figura del monje jerónimo del Real Monasterio del Escorial no ha sido estudiada de forma sistemática, con rigor investigador y consultando fuentes. El conocimiento que se tiene de él procede principalmente de cuatro autores, que, por orden cronológico y con diferente solvencia, lo han tratado, y cuyas obras recogemos en la bibliografía:

- B. Vicuña Mackenna. Escribe en el siglo XIX basándose en opiniones de personas que conocieron los hechos; son datos e informa-

1 CAMPOS 2009b; CAMPOS 2009a. Pueden consultarse los textos completos en la web del Museo de la Inquisición de Lima: http://www.congreso.gob.pe/museo.htm (Inquisición > Temas Inquisitoriales). 
ción de crónica que hay que comprobar para rehacer la veracidad de las afirmaciones y la exactitud de los hechos consignados. Por ser uno de los primeros autores peruanos que cita al monje jerónimo, algunas de sus opiniones se han aceptado de forma inconmovible ${ }^{2}$.

- J. T. Medina. Trata tangencialmente al P. Cisneros a propósito del escándalo ocasionado con la publicación del Elogio del virrey Jáuregui, obra de J. de Baquíjano, y su nombramiento por el virrey como revisor de bibliotecas de la ciudad y revisor de los libros que llegasen al puerto. De este autor va a partir la creencia (luego amplificada por otros) de que muchos de los libros prohibidos que se extendieron por la ciudad los guardaba el monje jerónimo³ ${ }^{3}$

- C. A. Romero. Se ciñe al tema del P. Cisneros como bibliotecario de la Universidad Mayor San Marcos y mientras desempeñó oficialmente el cargo, con enorme competencia y grato recuerdo. Su estudio se encuentra muy bien documentado y es riguroso, aunque todavía no se conocen los libros que ingresaron a la universidad desde la biblioteca particular del padre jerónimo bajo la forma de donación íntegra ${ }^{4}$.

- J. de Mendiburu. Es el primer autor que trata la figura del P. Cisneros de forma completa. Al ser su Diccionario una obra concebida como presentación de los personajes no cita fuentes, y son pobres las referencias bibliográficas que incluye. Aunque la biografía es completa y está bien desarrollada como ensayo, muchos aspectos importantes quedan en el testimonio de sus palabras y de ahí los han tomado los demás autores citando la obra como fuente fundamental, lo cual hace necesaria una revisión de sus afirmaciones 5 . Ignoramos las fuentes que revisó este gran político peruano. Como organizador del Archivo General de la Nación tuvo acceso a la

2 VICUÑA 1860. Se hicieron varias ediciones en los siglos XIX y XX.

3 Véase MEDINA 1904-1907. T. I: 110 y 114.

4 Véase ROMERO C. A. 1927.

5 Véase MENDIBURU 1932. T. IV: 159-166. 
documentación existente sobre Cisneros aunque no nos consta que figure este dato ${ }^{6}$.

A partir de aquí, los autores han repetido los mismos hechos biográficos con pequeñas variaciones y sin ninguna aportación documental importante. A comienzos del último tercio del pasado siglo XX, F. Romero, estudiando la figura de Toribio Rodríguez, se aproximó en serio al padre jerónimo debido a la estrecha relación que tuvieron ambos personajes. Aunque breve, hace una semblanza buena y completa de fray Diego. Además, es el primer autor que consultó gran cantidad de fuentes peruanas y españolas, y quizás admirado por la figura del jerónimo confiesa que su propósito era escribir una biografía; desconocemos si esta se llegó a publicar, pues no la hemos localizado en nuestra detenida búsque$\mathrm{da}^{7}$. A pesar de sus aciertos toma de Vicuña Mackenna una idea falsa por la que ambos demuestran no conocer el sistema interno de la vida de los jerónimos ni el sistema de los capítulos o reuniones conventuales ${ }^{8}$.

Debido a que consigna erróneamente algunos aspectos de la vida interna de la comunidad jerónima del Escorial, deducimos que Toribio Rodríguez no conoce el funcionamiento de esta por lo cual llega a conclusiones erróneas, como es el supuesto motivo de la derrota del P. Cisneros cuando aspiraba a la prelacía.

6 Además de información individual, en la Sección de Asuntos Eclesiásticos (Cabildo Eclesiástico) del Archivo General de la Nación hay legajos catalogados como "San Lorenzo del Escorial, 1641-1822".

7 Véase ROMERO F. 1973: 108-111; 169-179; especialmente caps. V y VII.

8 Afirma Benjamín Vicuña (1860: 114) que Cisneros "había sostenido en su convento del Escorial en España, un ruidoso capítulo, en el que fue vencido, a pesar de sus influencias [en la Corte]". El 'capítulo' de la comunidad era el lugar donde el prior exponía a todos los miembros de la comunidad los asuntos más graves que afectaban a temas espirituales o materiales, y después de intervenciones por parte de los religiosos que quisieran dar su opinión, se pasaba a votar secretamente la propuesta, que era aprobada o rechazada según el resultado del escrutinio. En los capítulos nunca se votaba al superior; solo la aceptación de un candidato a la toma de hábito, a la profesión religiosa y a las sagradas órdenes. Capítulo con carácter electivo era el Capítulo General —que durante siglos se celebró en la Casa Generalicia donde nació la Orden de San Jerónimo, que fue San Bartolomé de Lupiana (Guadalajara, España)—, al que asistían con voz y voto los superiores de todos los conventos de la orden; también era la instancia superior para crear, modificar o derogar las leyes. Por lo tanto, no tiene que ver nada con las sugerencias apuntadas por Mackenna y Romero.

Bol. Acad. peru. leng. 54(54), 2012 


\title{
II. Bibliotecario del Real Monasterio del Escorial
}

\begin{abstract}
Para un 'homo universalis' del siglo XVI, la Biblioteca Real del Escorial podía ser algo así como el 'hortus clausus' renacentista — por monasterio y por paraíso- que imaginaba el autor oriental de las Mil y una noche'; aunque el gran humanista Arias Montano sufriese en el Escorial, no por los libros allí reunidos que tanto amó y organizó con sabiduría y conocimiento (hasta dejar sus textos personales en aquellos cálidos anaqueles diseñados por Juan de Herrera), sino por el choque de sus proyectos y los intereses del monarca del que era súbdito y capellán (Campos 2010: 16-72) ${ }^{10}$. No en vano el cronista Juan Páez de Castro, al escribir al monarca un memorial sobre la importancia de establecer bibliotecas, redacta quizás el manifiesto cultural más lúcido de todo el renacimiento español al destacar el valor y la importancia de los libros:
\end{abstract}

Por causa de las librerías perdieron muchas naciones el nombre de bárbaras, y muchas ciudades fueron frecuentadas de los principales hombres del mundo, y se ennoblecieron con estudios y universidades. Las librerías son causa que se haga amistad y concordia entre muy diversas acciones por vía de letras. Viénense con seguridad los principales ingenios a donde están las fuentes de la doctrina (...). Tras los libros, los sabios y, tras ellos, los que quieren ser discípulos $(. . .)^{11}$.

9 "Un armario de libros es el más hermoso de los jardines. iY un paseo por sus estantes es el más dulce y el más encantador de los paseos”. Relato de la noche 895. Por eso luego J. L. Borges (1985: 4) afirmará: "Y me imaginaba el paraíso / bajo la especie de una biblioteca".

10 Aun habiendo sido nombrado Librero Mayor de la Biblioteca por Felipe II no eran honores vacíos los que buscaba, y por eso se lamenta ante el secretario Gabriel de Zayas con una frase bellísima y cargada de significados: "Todas estas cosas presentes y fervientes y otras muchas que de estas nacen y nacerán, son bastantes para criar melancolía en las piedras, y aun desbaratarlas y quebrantarlas con ella, cuánto más con el cuerpo sujeto tan frágil como el mío". San Lorenzo del Escorial, 10-X-1579. Texto, en CODOIN, vol. XLI, p. 408.

11 Biblioteca Real del Escorial, ms. \&.II.15, ff. 190-195. Biblioteca Zabálburu, Madrid, doc. 80-192; en la parte superior dice: "Biblioteca del Escorial"; Memorial autógrafo de Ambrosio de Morales sobre el orden de la Biblioteca del Escorial, ms. \&.II.15, f. 197; MALVADI 2011; ARZE 2012. 
Para un monje intelectual y artista, trabajar en el scriptorium y en la biblioteca conventual era vivir anticipadamente en la gloria porque aquellos lugares eran el ónfalo del edificio y el ámbito espiritual en el que los privilegiados pasaban horas de dicha; no en vano allí se conservaban los códices miniados con la Palabra de Dios y los comentarios de los Padres a las Sagradas Escrituras y las reglas monásticas. Lejos quedaba la dureza del trabajo material del copista medieval:

Quien quiera que te acerques a leer, acuérdate de mí, el escritor y pecador Florencio; tal vez así desaparezcan mis delitos y pueda presentarme tranquilo ante el Redentor de los Hombres (...). El trabajo del que escribe es alimento del que lee. Él se debilita en el cuerpo, el otro aprovecha en el alma. Por tanto, aquellos que sacáis provecho no os olvidéis de la fatiga del trabajador (...). El que no sabe escribir cree que no hay tanto trabajo en ello; más para que tú lo sepas quiero especificarte las molestias que se sufren al escribir: trae la oscuridad a los ojos, encorva la espalda, hace mal al vientre y a las costillas, deja doloridos los riñones y trae magullado todo el cuerpo. Por tanto, lector, pasa lentamente las hojas, ten los dedos lejos de las letras; pues como el granizo quita la fecundidad de la tierra, así el lector descuidado destroza la escritura y el libro. Escucha una confidencia: lo mismo que es grato al navegante el último puerto, así es suave para el escritor el verso postrero ${ }^{12}$.

Para fray Diego Cisneros, lingüista e intelectual, haber alcanzado por primera vez el puesto de segundo bibliotecario de la Librería Real del Escorial (c. 1765), con derecho a acceder al primero - que en terminología actual equivaldría al cargo de director-, era una dignidad que venía a reconocer sus méritos personales e intelectuales, lo cual lo equiparaba al personal distinguido del otro gran centro cultural de la corte de Madrid que era la Real Biblioteca de Palacio ${ }^{13}$.

12 Véase PÉREZ 1970. T. II: 309; PÉREZ 1934. T. II: 199-207 y LINAGE 2008: 297-309.

13 ZARCO, J. 1924, p. XC. El cargo fue creado por Carlos III "para que el oficio se sirviese con decoro y dignidad". Por oposición de la comunidad laurentina, basada en principios subjetivos muy distantes a los afanes intelectuales, ningún bibliotecario segundo ascendió a primero. Biblioteca Real del Escorial, ms. H.I.11, f. 107.

Bol. Acad. peru. leng. 54(54), 2012 
De su actividad como bibliotecario de San Lorenzo el Real se conservan unas cartas que dejan testimonio de su trabajo. Dos están dirigidas a don Juan de Iriarte, bibliotecario de Palacio, y tratan sobre un fragmento de Zenodoto existente en la librería escurialense; una de las misivas es del 3 de febrero de 1768; la otra no consigna día ni mes, pero es del mismo año. También se guarda un informe sobre la erección de oratorios en las celdas de los religiosos, de agosto de $1768^{14}$. Existen, además, unas cartas del P. Cisneros escritas posteriormente desde Lima y dirigidas a los administradores del Nuevo Rezado de la Orden de San Jerónimo. En dichas cartas, el jerónimo habla del envío de diversos modelos de libros y de las muchas vicisitudes que sufren los envíos hasta llegar a sus manos; asimismo, realiza comentarios sobre algunas noticias escurialenses de las que se había enterado ${ }^{15}$.

En la Biblioteca Nacional de Madrid existen cuatro cartas de fray Diego dirigidas a don Juan de Santander, Bibliotecario Mayor de S. M. En ellas se habla sobre el intercambio de libros repetidos entre las dos Librerías Reales; las cartas están fechadas entre mayo y septiembre de 1769. El contenido de las mismas describe la forma de materializar el proyecto: elaborar los listados; cotejar los libros — hebreos, griegos, árabes y latinos-; y preparar los cajones, que fueron dos. Sin embargo, hay algunas alusiones que detallan la operación; por ejemplo, el P. Cisneros menciona que quería tenerlo todo terminado para cuando llegase la Corte en las "jornadas" de ese año, y para "cerrar la boca a algunos que en Madrid dudaban de que esto se pudiera llegar a efectuar"; también dice que él estaba solo y le ayudaba don Juan Pellijero, el cual le fue recomendado por el señor Santander, y que ambos "ganamos la ración"16.

14 Biblioteca Real del Escorial, mss. Z.IV.21, ff. 39-49v, y Z.IV.23, ff. 335-345v; cfr. Catálogo, t. III, pp. 174 y 182. J. de Iriarte reconoció los conocimientos de lengua griega del P. Cisneros, Regiae Bibliothecae Matritensis Codices Graeci: Mss. Matriti. Anno MDCCLXIX, vol. prius, p. 308 .

15 Biblioteca Real del Escorial: Lima, 20-VIII-1785 (XXVIII-54); 6-II-1790 (XXIX-26/1); 16-X-1790 (XXXIX-26/2); 1790 (XXIX-26/3); 25-I-1792 (XXIX-42/1); 23-XII-1807.

16 Biblioteca Nacional, Madrid, Relación de los libros y papeles de la Secretaría de la Biblioteca Nacional que pasan a la Sección de Manuscritos de la misma en 1903, BN-Archivo, 0133/04. Carta de 25-VIII-1769. 
En esta situación personal bonancible y prometedora e ignorándose las causas que originaron la solución adoptada, deja el monasterio. Abandona el cargo y el trabajo en la Biblioteca — sin alejarse mucho del Escorial—, y poco tiempo después se ofrece para trasladarse al Perú para atender los intereses materiales que allí tenía el Monasterio en unas encomiendas que había dejado Felipe IV vinculadas a una fundación pía funeraria realizada por miembros de la familia real (Campos 2009a: 178182). Sumada a estos hechos estaba la administración de la venta de libros litúrgicos conocida como Nuevo Rezado, la cual Felipe II había concedido en régimen de monopolio editorial —impresión y distribución-, desde el comienzo de la reforma tridentina, a los jerónimos del Escorial para todos los territorios de las coronas de Castilla, Aragón y Nuevo Mundo ${ }^{17}$.

Desde hace siglos, la Orden de San Jerónimo ha cargado con el estigma histórico de que se la crea económicamente poderosa e influyente en el ámbito político. Fue acusada ante varios reyes de poseer ingentes caudales, siempre con intereses por parte de los nobles difamadores que buscaban provocar la enemistad con los monarcas y beneficiarse de los bienes de la orden en caso de que le fuesen enajenados ${ }^{18}$. Estudiado este tema por nosotros no vamos a volver sobre ello, pero sí hemos comprobado que en recientes estudios se sigue insistiendo en tópicos historiográficos que no cuesta mucho verificar y corregir ${ }^{19}$. Hasta el mismo Mendiburu afirmaba ya hace ochenta años que "las rentas del Escorial no estuvieron bien manejadas, fuese por incapacidad e incuria de los administradores o por defraudaciones: pues es constante que existían cuantiosos rezagos

17 Véase CAMPOS 1998. T. II: 505-548; MEDIAVILLA 2009: 147-168 у MEDIAVILLA 2010: 467-534.

18 CAMPOS 2008: 113-143. El Abate Tiron (1851. T. II: 182) califica a la Orden de San Jerónimo como "una de las más ricas y poderosas"; A. Castro (1970: 64, 66-68) habla de "inmensas riquezas"; C. Sánchez Albornoz (1997. T. I: 342-343) dice que "eran ricos"; M. Bataillon (1983: 234) asegura que era una orden "poseedora de bienes". Siguiendo esta tesis, más recientemente J. Blázquez (1986: 61) califica a la orden de "económicamente fuerte". Véase también ZARCO 1930: 27-29.

19 B. Vicuña Mackenna inició el siglo XIX con un cuádruple error, como fue afirmar que el P. Cisneros fue a América por decisión de la reina María Luisa de Parma, que lo envió con grandes prerrogativas y el privilegio de vender los libros litúrgicos con lo que obtuvo una renta pingüe (1860: 114). Véase también CLÉMENT 1997. T. I: 33. Bien documentado el déficit constante se puede encontrar en CAMPOS 2009a: 186-199.

Bol. Acad. peru. leng. 54(54), 2012 
por cobrar" (1932. T. IV: 159), y cita algunos casos de bastantes miles de pesos.

Desconocemos los motivos concretos desencadenados en el monasterio que provocaron la salida del cenobio del P. Cisneros. Sin duda fueron graves, pues lo llevaron a buscar destino en un lugar tan lejano del Escorial como era Lima (lugar en el que se quedaría para siempre), renunciando a todo lo que había conseguido y cambiando completamente de vida. Las Actas Capitulares dicen que antes de marchar a Perú ya estaba fuera del monasterio y pidió perdón a la comunidad por los malos ejemplos que con su conducta hubiese podido dar ${ }^{20}$. Mendiburu señala que

[Cisneros] había dejado sus claustros del Escorial impelido por una tormenta que contra él desató el odio envidioso de unos cuantos monjes. Desairáronle en su pretensión de obtener la prelacía de su orden, porque sus luces humillaban a los que nunca pudieran igualársele en el saber, y a los que no sufrían, por soberbia, las distinciones y predilección que le dispensaba la princesa María Luisa (después reina como esposa de Carlos IV) de la cual Cisneros había sido confesor.

Afectada con el golpe sufrido por el religioso a quien protegía, había conseguido se le presentara para un obispado: mas no llegó a verificarse así por la absoluta negativa del padre Cisneros a admitir aquella elevada dignidad. Y conviniéndole alejarse del monasterio, alcanzó por medio de la misma princesa se le permitiera residir en América. Tales fueron los antecedentes del nombramiento que se le otorgó de administrador de las encomiendas y demás intereses de San Lorenzo del Escorial en el Perú, y con más facultades y atribuciones que sus Predecesores (Mendiburu 1932. T. IV: 160-161).

A partir de aquí recogerán este dato los historiadores. No hemos localizado ni en Lima ni en Madrid información concreta sobre este asunto que aclararía un pasaje importante de su vida. Que el monje bibliotecario tuvo un enfrentamiento con la comunidad de San Lorenzo

20 Libro de los Actos Capitulares del Monasterio de San Lorenzo el Real. San Lorenzo del Escorial 2004, II.2, n. ${ }^{\circ} 611.2$, p. 460. 
puede ser verosímil por el hecho de salir a vivir fuera del monasterio meses antes de decidir ir a Perú; pero también pudieron existir otros motivos, ya que en Madrid los monjes del Escorial tenían la librería de los libros litúrgicos, la cual era un anexo al monasterio de San Jerónimo el Real (donde recientemente se ha hecho la ampliación del Museo del Prado, integrando el claustro de granito). Esta librería era conocida como "Cuarto del Nuevo Rezado", y estaba administrada siempre por un jerónimo de San Lorenzo.

El haber sido confesor de la princesa María Luisa de Parma solo pudo ser posible de forma extraordinaria cuando la familia real se trasladaba oficialmente todos los años al Real Sitio durante el otoño, estancia a la que se conoció como "tiempo de jornada". Mientras transcurría este período, la mayoría de monjes sacerdotes de la comunidad religiosa eran solicitados para asistir espiritualmente a tantos distinguidos personajes, y sabemos que hubo casos de estrecha amistad entre algunos jerónimos y miembros de la familia real y la nobleza ${ }^{21}$. Hasta ahora no hemos encontrado ninguna referencia en el Archivo del Palacio Real de Madrid. Por las circunstancias políticas que vivirían España y los territorios americanos a comienzos del siglo XIX, el P. Diego Cisneros fue el último jerónimo que estuvo en Lima administrando in situ y defendiendo los intereses económicos y las que allí tenía el Monasterio del Escorial.

\section{Miembro de la Sociedad de Amantes del País de Lima}

La Sociedad de Amantes del País de Lima se creó privadamente en 1790, aunque la erección formal, la presentación y la aprobación de los estatutos fue en 1792. Esta sociedad tuvo su origen en las reuniones ilustradas que habían surgido dos años antes entre un grupo de amigos en torno a la figura de José Rossi Rubí, joven milanés afincado y casado en la Ciudad de los Reyes a la que había llegado a mediados de la década de los ochenta (Poupeney 2007a: 41-65). Sus inquietudes ilustradas y musicales le hicieron trabar amistad con tres jóvenes peruanos a los

21 Véase CAMPOS 1993: 145-168; CAMPOS 2007: 269-313 y ZARCO 1930: 137-138.

Bol. Acad. peru. leng. 54(54), 2012 
que luego se sumaron otros dos; con ellos fundaron una Academia Filarmónica de corta existencia pero que sirvió para estrechar lazos humanos e intelectuales — de estos filósofos como sellarán ellos—, que fraguarían en la creación de la Sociedad de Amantes del País y en su gran obra el Mercurio Peruano, como ellos mismos explicaron:

En el año de 1787. Hesperiófilo [J. Rossi] puso término a sus viajes por un engaño de la fortuna, y se domicilió en esta Capital. Su espíritu vivaz, ardiente e inquieto no encontraba pábulo suficiente en las tareas privadas de su obligación, ni en las recreaciones del público. La equitación y la caza le proporcionaban un exercicio agradable: la lectura y la meditación eran los entretenimientos de su gabinete. En un paseo de Lurín [pueblo que distaba cinco leguas de la capital] conoció a Hermágoras [J. M.a Egaña], Homótimo [D. Guasque] y Mindirido [desconocido], todos tres jóvenes amabilísimos. Hermágoras desde muchos años antes entretenía una buena tertulia en su casa, a donde concurrían además de los dos nombrados, Agelasto [desconocido] y Aristio [J. H. Unanue]. Hesperiófilo tuvo el honor de quedar agregado a esta pequeña sociedad. Sus concurrencias eran indefectiblemente todas las noches desde las ocho hasta las once: en ellas solo se trataban materias literarias, y se examinaban las noticias públicas. La detracción, el juego, las vagatelas y los cuentos amatorios estaban proscritos de este congreso de filósofos ${ }^{22}$.

Por ideales y fines, la Sociedad limeña estaba en línea con las homónimas españolas y las hispanoamericanas que nacerían por esos años. La Ilustración fomentó en Europa occidental que muchos de sus partidarios, reunidos en academias y sociedades privadas, plasmaran sus inquietudes intelectuales en unos proyectos de reformas de la sociedad

22 "Historia de la Sociedad Académica de Amantes del País, y principios del Mercurio Peruano", en Mercurio Peruano, t. I, n. ${ }^{\circ} 7$ (23-I-1791) 49-50; continúan la historia de la Sociedad en las pp. 50-52. En otra parte recordarán sus orígenes diciendo que fue una "Sociedad de muy pocos Literatos en número, congregados privadamente en 1790 por solo su amor a la sabiduría..." [Ibídem, t. X, n. 329 (27-II-1794) 136], y que la erección formal fue en 1792 [Ibídem, t. X, no 335 (20 III-1794) 188]; también describirá sus orígenes el presidente Ambrosio Cerdán, como "una asociación de varios Literatos que voluntariamente dedicaban sus tareas al Mercurio, como la instancia que hacían quatro individuos que la suscribían" [Ibídem, t. X, n. 330 (2-III-1794) 145]; CLÉMENT 1997. T. I: $21-30$. 
en general que se debían materializar en la prosperidad, el bienestar y la felicidad de los naturales de los respectivos países por medio del desarrollo de la agricultura, el fomento de la industria, las ciencias útiles, las artes y el comercio. Esos proyectos fueron asumidos por los monarcas ilustrados y sus Gobiernos en las reformas realizadas desde el poder — "todo para el pueblo pero sin el pueblo"-, que aunque no lograron su objetivo sí produjeron un cambio notable de la sociedad.

En España, las tertulias culturales que decenios atrás habían originado las Reales Academias ahora daban un paso más amplio en fines y contenidos. Se extendieron por toda la geografía nacional a través de otras Academias que surgieron en muchas ciudades donde había un pequeño grupo de habitantes con buena formación académica e intelectual e inquietudes culturales.

Bajo la iniciativa de don Javier María de Munive, conde de Peñaflorida y otros dos amigos — los Caballeritos de Azcoitia_, se creó en 1748 una Sociedad Económica o Académica que sería la Real Sociedad Bascongada de Amigos del País (sus estatutos datan de 1765). Por impulso de don Pedro Rodríguez de Campomanes y a través de sus obras -Discurso sobre el fomento de la industria popular (1774) y Discurso sobre la educación popular de los artesanos (1775)—, tres amigos suyos —Vicente Rivas, José Faustino Medina y José Almarza-, solicitaron a Carlos III la aprobación de los estatutos de la Real Sociedad Económica Matritense de Amigos del País (1775), primera con este nombre glorioso ${ }^{23}$. Once años más tarde se acercan ya al centenar; pocos años después estas sociedades se habían trasplantado a los territorios de América y Filipinas en donde florecían en importantes ciudades ${ }^{24}$.

23 Una buena y completa síntesis se puede encontrar en ENCISO 1987: 13-56; ENCISO 2010; varios 1972; DEMERSON P., DEMERSON J. y AGUILAR 1974; y TELLECHEA.

24 Con nombres similares o el mismo, encontramos sociedades en: Manila, en 1781; Santiago de Cuba, en 1787; Lima, en 1790 y 1822; Santiago de Mompox (Colombia), en 1790; Quito, en 1791; La Habana, en 1793; Guatemala, en 1795; México, en 1799; Santa Fe de Bogotá, en 1801; Cartagena de Indias (Colombia), en 1812; Puerto Rico y Santiago de Chile, en 1813; Chiapas (México), en 1819; Mendoza (Argentina), en 1822; Guayaquil (Ecuador), en 1825; Caracas, en 1829; Matanzas (Cuba), en 1830; Panamá, en 1834; Santa Marta (Colombia), en 1835 , etc.

Bol. Acad. peru. leng. 54(54), 2012 
Eran conscientes del objetivo que cumplían y dejan constancia de ello:

La protección, el tiempo y la constancia nos irán insensiblemente conduciendo al brillante estado que deseamos. Entretanto seguiremos en el desempeño del Plan hasta aquí observado, repuntando por fruto precioso de nuestras tareas la utilidad del Mercurio. Sin él carecería el Público de las muchas luces que se le van esparciendo casi en todas las ciencias, que es lo que más interesa para la felicidad del Pueblo Americano ${ }^{25}$.

Medio siglo después de estos hechos y habiendo conocido a personas que los vivieron, Benjamín Vicuña cree que la fama de la Sociedad de Amantes del País y del Mercurio se debió sobre todo al eco que encontró en la historiografía posterior, y reduce su importancia a la de una buena publicación en consonancia con el tipo de ideales que movían a la entidad promotora $^{26}$. María Luisa Rivara Tuesta piensa que el prestigio del periódico es un fenómeno anterior a la valoración historiográfica y que la publicación del Mercurio "aviva y fomenta, a través del periodismo, el espíritu del siglo que contribuye a fomentar el movimiento separatista al afirmar el sentido de nacionalidad y de amor a la patria" ${ }^{27}$.

25 Mercurio Peruano, t. VI, n. ${ }^{\circ} 174$ (2-IX-1792) 1-2. "Los hombres que redactaron el Mercurio Peruano, afirmados en su preocupación por la tierra peruana y por el destino del habitante alentaban una concepción universal de la cultura y una inquietud casi obsesivas por las nuevas ideas de la Ilustración", NÚÑEZ 1977: 489.

26 "El Mercurio Peruano no era un registro de ideas ni un programa de principios. En vano el filósofo exhumaría sus páginas, preciosas en otro sentido, para sorprender en ella los secretos y los amagos del trastorno innovador que venía por aquellos años agitando al universo y a la humanidad toda. Órgano de una sociedad de literatos y de sabios, no pasaba por tanto más allá del rol de un boletín científico, y de una revista literaria, de mérito sobresaliente es verdad, y aun superior a todo lo que la vanidad nacional podría ponderar hoy día, pero sin vuelos atrevidos, sin acción en lo futuro, sin programa social no político", VICUÑA 1860: 102-103. Se puede ver la declaración de principios que Jacinto Calero y Moreira (llamado Crisipo en la Asociación) expuso como manifiesto editorial donde se daba a conocer la publicación: Prospecto de papel periódico intitulado Mercurio Peruano de Historia, Literatura, y Noticias públicas, que a nombre de una Sociedad de Amantes del País, y como uno de ellos promete dar a luz. Lima, 1790.

27 "Introducción" a Ideólogos de la Emancipación Peruana, p. 4; completo, pp. 1-50. Versión digital: http://eltalondeaquiles.pucp.edu.pe/sites/eltalondeaquiles.pucp.edu.pe/files/ ideologosdelaemancipacionperuana.pdf 
Creemos que las páginas del Mercurio fueron un valioso ejemplo de peruanidad en versión de ideales ilustrados y cierto sentimiento nacionalista que estaban evolucionando tan deprisa como los tiempos ${ }^{28}$. No en vano muchos de los miembros de la Sociedad de Amantes del País serían (muy pocos años después) abiertos defensores de la independencia y militantes políticos de varias tendencias, influidos de forma directa por la Constitución de 1812, y la estadía de muchos líderes americanos en Cádiz, París y Londres ${ }^{29}$. Víctor Peralta Ruiz haciendo un interesante análisis de los historiadores peruanos de la primera mitad del siglo XX - la generación del Centenario y los vinculados al Instituto Riva Agüero-, asegura que entre ellos "hubo un consenso en que la idea de la patria peruana fue confeccionada por el cuerpo de ilustrados que colaboró en la publicación Mercurio Peruano en la última década del siglo XVIII. Tal sentimiento nacional se fortaleció con el ideario precursor de un reducto grupo de criollos" (Peralta 2006: 174).

La Sociedad de Amantes del País tuvo existencia y justificación en y para su obra periodística; las otras sociedades similares tuvieron vida propia como se refleja en las actas de las reuniones de los miembros mientras que en la de Lima solo se trataban asuntos relacionados con el Mercurio — contenidos, economía, elección y renovación de cargos, etc.- que era lo que terminó justificando su existencia y la preocupación e interés de sus integrantes ${ }^{30}$. Así quedó expuesto por su presidente Ambrosio Cerdán y Pontero en las páginas del periódico al editar los estatutos de la Sociedad ${ }^{31}$.

28 VARGAS 1971: 123; CLÉMENT J. 1997: 105-260; GUIBOVICH 2005: 46-66; POUPENEY 2007b: 25-40; CAMPOS 2009a: 177-229; CAMPOS (en prensa).

29 Véase FERNÁNDEZ 2000; MORÁN 2008; ÑIQUE 2012: 55-58; CASSAGNE 2012: 161-186. Véase también en la Biblioteca Jurídica Virtual del Instituto Jurídico de la UNAM (México): http://biblio.juridicas.unam.mx/libros/7/3078/10.pdf

30 "El Mercurio no era un periódico noticiero ni se limitaba a dar inocentes noticias; fue ante todo un promotor de la cultura y un activo animador del conocimiento de nuestra realidad en todos sus aspectos". VARGAS 1971: 124.

31 Mercurio Peruano, t. X, n. ${ }^{\circ} 329$ (27-II-1794) 135-142. En los números siguientes continúa haciendo la crónica histórica de la Asociación, Ibídem, n. ${ }^{\circ} 330$ (2-III-1794) 143-150, n. ${ }^{\circ} 331$ (6-III-1794) 151-158, y n. ${ }^{\circ} 332$ (9-III-1794) 159-165.

Bol. Acad. peru. leng. 54(54), 2012 
A comienzos de 1793, con dos años de existencia, se publicó un análisis anónimo — mitad confesión, mitad defensa-, en el que se explicaba lo que se había hecho justificando las circunstancias que las habían motivado, debiéndose el cambio a la realidad cotidiana y a la propia evolución del pensamiento de los miembros de la Sociedad. Esto ocurrió cuando terminaron con la etapa romántica tardía que tuvo inicialmente el pequeño grupo de jóvenes promotores y se dio entrada a otros nuevos socios. El autor de la larga introducción o editorial al tomo VII no sabía que al periódico le quedaba año y medio de existencia:

En fin llegó el gran día vaticinado en el papel de 23 de Enero de 91 [Mercurio, t. I, n. ${ }^{\circ}$ 7]. Séanos, pues, lícito apartar de nuestros rostros la mascarilla de los nombres griegos, que ha ocultado los verdaderos de los que han elaborado el Mercurio hasta el presente. Vamos a descubrirnos a la faz del Universo, presentándonos sin más escudo que el amor patriótico que nos ha distinguido siempre (...).

El verdadero punto de vista, baxo del qual se debe mirar la mayor parte de los opúsculos del Mercurio, y el Mercurio mismo, es el de que sus Autores no han sido Escritores de profesión. Jóvenes todos, empleados algunos en el servicio del Rey, otros graduados en los diversos exercicios de la Universidad, otros Ministros del Altar, hemos abrazado unánime y gustosamente la difícil empresa de abrirnos una nueva senda, que nos conduzca al término feliz de ser útiles a la Patria (...). Para meditar, escribir, extender nuestros pensamientos, cuidar de la imprenta, buscar libros, congregar nuestras juntas no había más tiempo que el que usurpábamos a la diversión y al sueño (...).

Este sentimiento precioso [carecer de una buena biblioteca y de manuscritos originales que sirvieran para la formación de los miembros] es característico de nuestra Sociedad. Todos sus Individuos piensan de un mismo modo quando se trata del servicio de la Patria y de la Nación. Pero en las demás materias opinables, y en las questiones de pura especulación, no se impide que haya entre uno y otro alguna discrepancia de conceptos. Nuestras juntas Académicas no han aspirado nunca a tiranizar la opinión de los Socios que respectivamente trabajan para el Mercurio (...).

Desde el retiro filosófico y obscuro de nuestra Academia respetamos y veneramos esos genios de superior orden (...). Hemos recogido aquellas 
noticias que por pequeñas, por confusas o por nuevas, no han entrado en el plan de sus obras [de los grandes autores] (...).

Los Individuos de la primitiva Sociedad miran con ánimo sereno este momento en que va a identificarse la idea de sus escritos con las de sus personas. Los que entran de refresco a sostener y hermosear el edificio del Mercurio, sufren con anticipación el mismo juicio. Unos y otros no tenemos otro deseo, que el de merecer la aprobación de los buenos patriotas ${ }^{32}$.

La Sociedad de Amantes del País tuvo el orgullo de poder comprobar cómo el periódico era conocido y apreciado en la Corte. Cuando en 1793 se hace una exposición de la situación del periódico y de las personas que ocupan los cargos se inserta el texto del oficio remitido al virrey desde Madrid en el que se comunica que "El Rey tiene noticia de la publicación de un periódico 'en que se tratan curiosos asuntos de Literatura, Comercio, Historia y otras Ciencias', y se ordena se remitan dos colecciones de los cuadernos que hayan salido hasta ese momento y de los que aparezcan en el futuro"33.

Gozosos incluía en la redacción del periódico una importante noticia sobre la difusión del Mercurio:

Por Cartas de España y Alemania se nos ha hecho saber la favorable aceptación que ha tenido el Mercurio en Madrid, Varsovia, Buda [Budapest], y Dresde, traduciéndose en las dos últimas Capitales algunos rasgos del primer Tomo para insertarse en los Periódicos de la Ungría y Alemania $^{34}$.

32 Mercurio Peruano, t. VII, núms. 209 y 210 (3-I-1793 y 6-I-1793) 1-19.

33 Aranjuez, 9 de junio de 1792. Mercurio Peruano, t. VII, n. ${ }^{\circ} 209$ (3-I-1793) 6 y 16. El virrey envió los Mercurios el 5-XI-1792, y desde Aranjuez le acusaron recibo de la llegada de la colección el 11-VI-1793, y así lo notificó al presidente de la Sociedad de Amantes del País, don Ambrosio Cerdán, en carta de 10-I-1794. Mercurio Peruano, t. X, n. ${ }^{\circ} 332$ (9-III-1794) 162-164. Actualmente no existen ejemplares en los fondos de la Real Biblioteca. En la lista de individuos que componían la Sociedad de Amantes del País, publicada el segundo año de la fundación formal de la misma y el cuarto de la publicación del Mercurio, el Rey figuraba como Protector, y en su nombre el Excmo. Señor Virrey, Ibídem, t. X, n. ${ }^{\circ} 335$ (10-III-1794) 188.

34 Mercurio Peruano, t. VI, n. ${ }^{\circ} 174$ (2-IX-1792) 1.

Bol. Acad. peru. leng. 54(54), 2012 
En la memoria que de su gobierno redacta el virrey en 1796 para informar a su sucesor de la gestión de su mandato, don Francisco Gil de Taboada y Lemus hace un detallado análisis del Mercurio Peruano calificándolo de "preciosa obra", y explica con objetividad los datos que conocemos por otras fuentes ${ }^{35}$.

En dicho análisis, le comunica que la Sociedad de Amantes del País era una asociación privada formada por hombres eruditos que llevaron a cabo con brillante lucimiento la publicación, y decidió transformarse en sociedad pública para atraer a su seno mayor número de literatos. Para eso redactó unas constituciones que se aprobaron interinamente hasta que S. M. resolviese lo conveniente. El interés que mostró el rey por el periódico fue un importante estímulo que se materializó en la orden dada al virrey para que solicitase dos ejemplares "para aquellos destinos que le considerase acreedores, pues quería atender y premiar su mérito".

Viendo el interés regio y la calidad de la publicación, el virrey Gil de Taboada les prestó todo su apoyo y, constituida formalmente la Sociedad, les permitió "franquear a los socios la Biblioteca de la Real Universidad y con ella una sala decente, en la cual pudiesen celebrar sus juntas”, y para apoyar materialmente los gastos de la edición les concedió de parte del rey una subvención de cuatrocientos pesos. Sin embargo, comenzó a notar que la publicación bajaba sus primeros niveles de calidad y "pasó oficio a la Sociedad para que le expusiese las causas de su acabamiento".

Luego reconoce los méritos personales del $\mathrm{P}$. Cisneros como persona ilustrada y por ser quien, como secretario, sostuvo el proyecto y editó a su costa el volumen duodécimo. Pero habiendo transcurrido un año, cuando redacta la relación, sin haberse publicado ningún nuevo volumen piensa que ha "concluido este importante periódico". Finaliza haciendo

35 Relación de gobierno del Excmo. Señor Virrey del Perú, Frey Don Francisco Gil de Taboada y Lemus. Año de 1796. Real Academia de la Historia, 9/1707, ff. 85-87v. También recoge el informe del virrey sobre el Mercurio J. T. Medina sin citar de qué copia lo toma (1904-1907. T. III: 222-223). 
un elogio del mismo, reconociendo el problema económico como causa de la desaparición del periódico, así como la falta de ayuda oficial:

El aprecio que mereció el Mercurio al soberano y a mí, al paso que las ventajas a la nación lo habrían ya restaurado si no lo impidieran los grandes objetos y necesidades de la corona que ocupan mi atención en los infelices tiempos que hacen tan amargo el fin del siglo $18^{36}$.

\section{Secretario, censor, redactor y editor del Mercurio Peruano}

El fruto más maduro de la Sociedad de Amantes del País de Lima, por calidad intrínseca y por los efectos que tuvo de impulsar y difundir los ideales de la Ilustración, fue la creación del periódico Mercurio Peruano. Aunque tuvo una existencia breve (tres años), marcó una huella profunda en la sociedad criolla limeña y peruana pudiendo distinguirse un antes y un después de esta aventura editorial de los Amantes del País.

Ha tenido que pasar mucho tiempo para que se comiencen a estudiar aspectos monográficos del Mercurio Peruano, como se puede ver en repertorios bibliográficos modernos, cumpliéndose el anuncio del mercurista anónimo:

Nuestros Nietos podrán suputar y confrontar por una parte el valor de las ideas y estilo del Mercurio, y por otra el estilo y las ideas de los demás Literatos, que en esta misma Era escribían para las prensas, y hermanaban sus escritos con los nuestros. El resultado que deduzcan de este juicio comparativo, fixará el legítimo término del poco o mucho mérito de nuestro Periódico ${ }^{37}$.

36 Edición facsímil, Lima 1964, 12 vols. El trabajo citado de J. P. Clément es el mejor y más completo que conocemos, ya que describe los aspectos externos del periódico y estudia el contenido y su ideología.

37 Mercurio Peruano, t. VII, n. ${ }^{\circ} 210$ (6-I-1793) 17. Además de los trabajos ya citados, ZETA 2000; NIETO 1956-1957; ENCISO 1957; LÓPEZ 1972; SALAS 1974; CLÉMENT 1979; HAMPE 1991: 297-312; RATTO 1993; MARIÁTEGUI 2002; BARRIGA 2002: 206-210; PUENTE 2008; REY 2008: 47-52.

Bol. Acad. peru. leng. 54(54), 2012 
En 1780 se produjo un serio problema entre el virrey y la Inquisición, el cual llegó hasta el Consejo de Indias. El choque estuvo motivado por la publicación del folleto laudatorio de José de Baquíjano con el discurso oficial con el que la universidad recibió solemnemente en 1780 al virrey don Agustín de Jáuregui (1780-1784) como vicepatrón de San Marcos, centro decano de las universidades americanas ${ }^{38}$. Los miembros del Santo Oficio acusaron al escrito de contener ideas peligrosas y reprobadas. Entre las medidas de control que se debían introducir para vigilar la entrada de las nuevas ideas propusieron la conveniencia de designar un visitador de librerías públicas y privadas para la ciudad. El virrey don Teodoro de Croix (1784-1790), que tenía buena amistad y apreciaba las cualidades del monje jerónimo, explica por qué eligió al P. Cisneros para el cargo:

cerciorado de la literatura, y demás buenas cualidades que para el desempeño de este asunto concurrían en el padre maestro fray Diego Cisneros, del Orden de San Jerónimo, le nombré para que, por lo que mira a la jurisdicción real, asistiese, luego que se le pasase el aviso oportuno, al reconocimiento de las referidas librerías, como igualmente de los cajones o facturas de libros que se introdujesen en esta ciudad, teniendo presente que en las listas que manifiestan los dueños o apoderados de aquellos, suelen venir las obras disfrazadas con distinto título y nombre del autor de que en la realidad tienen, cuya malicia era necesario precaver, reconociéndolas por su interior... ${ }^{39}$.

El P. Cisneros mantuvo una estrecha amistad con Toribio Rodríguez de Mendoza. Esta fue iniciada por el clérigo, posiblemente por la compra de libros litúrgicos al monje del Escorial, y ampliada al comprobar la

38 Elogio del Excelentísimo señor don Agustín de Jáuregui y Aldecoa; Caballero del Orden de Santiago, Teniente General de los Reales Ejércitos, Virrey, Gobernador, y capitán General de los Reynos del Perú, Chile, E, pronunciado en el recibimiento, que como a su Vice-Patrón, le hizo la Real Universidad de S. Marcos el día XXVII de Agosto del año de M.DCC.LXXXI, 4. ${ }^{\circ}, 82 \mathrm{pp}$.

39 Archivo Histórico Nacional (Madrid), Inquisición, leg. 2214, exp. 25. Cuatro meses después, fray Diego sería denunciado ante el Tribunal, como veremos más abajo. Se equivocan Medina (1904-1907. T. I; XCVII; T. III: 110-114) y Clément (1997. T. I: 266) cuando afirman que lo nombró Gil de Taboada. A partir de 1784 el P. Cisneros firma algunas aprobaciones de originales para imprimir: MEDINA 1904-1907. T. III: 157 y 188; T. IV: 76. CAMPOS 2009a: 203-205. 
coincidencia en las nuevas ideas ilustradas sobre la educación de la juventud frente al obsoleto sistema escolástico. Esa sincera amistad con don Toribio y la buena relación con el virrey hicieron posible que el padre jerónimo intercediera ante don Teodoro de Croix para que el clérigo, que se había retirado al curato de Marcabal en Trujillo, regresase a Lima como director del Convictorio Carolino del que había sido vicerrector cuando comenzaron a tratarse, aprovechando la vacante del cargo ${ }^{40}$. También tuvo muy buena relación con Baquíjano, de quien fue compañero en la española Real Sociedad Bascongada de Amigos del País ${ }^{41}$.

Pocos años después tuvo contacto con el naturalista Humboldt durante la breve estancia del noble alemán en Lima, dejándolo impresionado por su alta formación intelectual y talante humano. En su diario este anota la grata impresión que le causó el padre jerónimo, aunque critique el ambiente decadente y decaído que vio en Lima durante su estadía de octubre a diciembre de $1802^{42}$.

En Lima no he aprendido nada del Perú. Allí nunca se trata de algún objeto relativo a la felicidad pública del reino. Lima está más separada del Perú que Londres, y aunque en ninguna parte de la América española se pecaba por demasiado patriotismo, no conozco otra en la cual este sentimiento sea más apagado. Un egoísmo frío gobierna a todos, y lo que no sufre uno mismo, no da cuidado a otro. Después de Urquiza y del barón de Nordenflycht (hombre de un carácter dócil y excelente) me ha interesado en Lima el padre Cisneros del Escorial, hombre de mucho talento y de un patriotismo poco común, aún entre los mismos españoles europeos $^{43}$.

40 MENDIBURU 1932. T. IV: 162; T. VII: 188. LEGUÍA 1922: 26. Exagera un poco Carlos Milla al negar "haber sido Rodríguez de Mendoza creación de Cisneros" (1986: 394).

41 PALACIO 1994: 386. Baquíjano figura como socio benemérito en Lima, de 1782 a 1793; y el P. Cisneros también lo hace como socio benemérito en Lima, de 1783 a 1793. Agradezco a la Prof. D. ${ }^{a}$ Izaskun Álvarez el dato facilitado.

42 LEQUANDA 1794. Preocupación que recoge el virrey Gil de Taboada en su Relación, de la que hablaremos más adelante, Real Academia de la Historia, 9/1707, ff. 73v-79.

43 VEGAS 1991: 87; NÚÑEZ y PETERSEN 1971: 9-25; MIRÓ QUESADA 1966: 251-268. Por sugerencia del virrey marqués de Avilés, el barón alemán fue huésped del también

Bol. Acad. peru. leng. 54(54), 2012 
En sus notas también lo califica de "sabio redactor de un periódico" ${ }^{4}$, y hay que recordar que Cisneros le regaló al barón una colección completa del Mercurio que luego hizo posible que se hiciese la traducción del periódico al alemán ${ }^{45}$.

La presencia de fray Diego Cisneros en la Sociedad de Amantes del País fue intensa e importante; fue pasando por varias etapas según las necesidades de la Sociedad y la disponibilidad del jerónimo, pero estuvo activo desde el primer momento suscrito al periódico con tres ejemplares ${ }^{46}$ :
- En 1793 figura como "Socio Honorario, nato, con voto" ${ }^{47}$. - En 1794 figura como "Académico y Censor" ${ }^{48}$, y pocas semanas después como "Socio Académico, Censor y Secretario de la Sociedad" $"$.

Pronto comenzaron a aparecer en el periódico las colaboraciones que publicó con el seudónimo de Archidamo ${ }^{50}$. El sistema de escoger nombres del mundo grecolatino fue adoptado al comienzo por los miembros de la Sociedad de Amantes del País, hasta que, a comienzos de

barón Nordenflycht y se alojó en su residencia del Paseo de las Aguas, frente a la Alameda de los Descalzos, lugar noble de la Lima del setecientos. Este sitio gozaba de una situación muy diferente de la que se percibe actualmente en aquella zona del Rímac. NÚÑEZ y PETERSEN 2002: 81, 246-250 y 254-255.

44 NÚÑEZ y PETERSEN 2002: 251.

45 CLÉMENT 1997. T. I: 269-270; NÚÑEZ 2002: 263. La edición alemana fue obra de F. J. Bertuch, y se publicó en Weimar en 1808, en dos volúmenes donde se recogían los trabajos más significativos. NÚÑEZ 1936; NÚÑEZ 1953: 45-48.

46 Mercurio Peruano, t. I, número previo al n. ${ }^{\circ} 1$ (I-1791) sin paginar. En las listas de suscriptores de 1792 no indica el número de ejemplares, cfr. ts. IV y VI, primeras páginas sin numerar.

47 Ibídem, t. VII, n. ${ }^{\circ} 210$ (6-I-1793) 23.

48 Ibídem, t. X, n. ${ }^{\circ} 332(9-$ III-1774) 161.

49 Ibídem, t. X, n. ${ }^{\circ} 335$ (20-III-1774) 188.

50 Reyes de Esparta, de la dinastía de los Euripóntidas: Arquídamo I (600-575 a. C., aprox.); Arquídamo II (469-424 a. C., aprox.); Arquídamo III (361-338 a. C., aprox.); Arquídamo IV (305-275 a. C., aprox.); Arquídamo V (228-227 a. C., aprox.). ¿Por qué escogió este apelativo? Él, que conocía bien la lengua griega, podía haber elegido un nombre genérico y no de persona. Se pueden ver los seudónimos de otros mercuristas en Mercurio Peruano, t. VII, n. ${ }^{\circ} 210$ (6-I-1793) 19-23. 
1793 se decidió que los artículos fueran firmados con los nombres reales de los autores ${ }^{51}$. Quizás por su tarea de secretario y censor no tuvo tiempo para escribir colaboraciones que estuviesen a la altura de su preparación. Como trabajos de investigación publicó:

- "Noticia histórica de los Concilios Provinciales de Lima", en el que hace un breve y completo recorrido a los seis concilios celebrados, censurando los errores cometidos por algunos autores en obras de divulgación histórica ${ }^{52}$.

- "Noticia histórica de los tres hermanos Pinelos"53. Es una pequeña biografía del mayor de los hermanos, don Antonio, gran jurista e historiador, miembro del Consejo de Indias y cronista mayor de Indias. En ella se resalta su vida entregada al estudio y a la investigación en un trabajo ingente como demuestran sus obras ${ }^{54}$.

Como secretario de la Sociedad editora escribió unos textos obligado por los acontecimientos, y las tres "Notas", como editor personal del tomo XII del periódico:

51 "Después de haber confesado públicamente los defectos verdaderos de nuestros papeles pasados, justificándolos al mismo tiempo de las falsas imputaciones que han sufrido, puede cada uno de nosotros publicar su nombre a descubierto. Dexamos los recelos a aquellas almas pequeñas que no pueden verse a sí mismas. No queremos más honor, ni distintivo que el de servir a la Patria”, Ibídem, p. 19.

52 Mercurio Peruano, t. I, n. ${ }^{\circ} 11$ (6-II-1791) 100-105. Teniendo en cuenta el carácter de información general que tenía el artículo no descendió a describir la disputa mantenida entre las diversas corrientes de los padres conciliares, y concluye afirmando que "celebrose esta sagrada junta con la paz y tranquilidad que todos saben", Ibídem, p. 105. Una visión del concilio, en VARGAS 1961, T. IV: 217-288, y más extensamente, en Concilios Limenses, Lima, 1951-1954, 3 volúmenes. Teniendo en cuenta que era un trabajo de divulgación cultural tampoco hace referencia al manuscrito de las Actas del Tercer Concilio de Lima existentes en la Biblioteca Real del Escorial, que conocía perfectamente, y es uno de los tres códices que existen en el mundo, ms. d.IV.8.

53 Ibídem, t. I, n. ${ }^{\circ} 20$ (10-III-1791) 177-184. Fue número monográfico. Según confiesa, al comienzo decidió escribir estas biografías siguiendo el proyecto que había tomado su compañero de la Sociedad, Hesperiófilo (el fundador, José Rossi), al publicar la semana anterior la biografía del P. Juan Pérez Menacho.

$54 \mathrm{Al}$ final se anuncia que "en otro Mercurio continuaremos con las vidas de sus dos hermanos Don Juan, y Don Diego”, Ibídem, p. 184. No llegó a publicarlas.

Bol. Acad. peru. leng. 54(54), 2012 
- "Introducción al Tomo XI del Mercurio Peruano", en la que comienza refiriendo que los malos presagios que se cernían sobre la publicación parecían vencidos gracias al celo del presidente de la asociación, la entrega del resto de miembros y la colaboración económica de algunos; sin embargo, la situación económica por la que atraviesa la publicación no es buena por falta de apoyo del público ${ }^{55}$.

- "Aviso al público" en el que comunica la aparición en Madrid del nuevo periódico Correo Mercantil de España e Indias (17921808); encuentra cierto parecido con el Mercurio y, por el tipo de contenido, invita a que todo buen español de Perú, especialmente la gente relacionada con las actividades comerciales debe tenerlo como herramienta de su actividad empresarial ${ }^{56}$.

- "Nota del editor" para agradecer al coronel don Adrián Fernández Cornejo el envío del diario de navegación que hizo por el río Bermejo, que le remitió a instancias suyas y que se publicó en el t. XII ${ }^{57}$.

- "Nota del editor" para explicar que la publicación en las páginas anteriores del periódico de la "Memoria histórica, y crítica sobre la introducción del Magnetismo en Manila", fue motivada por las noticias divulgadas en Lima sobre las portentosas curaciones hechas en la capital del archipiélago cuando llegó la expedición de Alejandro Malaspina. Defiende que, al margen de la veracidad de la información, la memoria "está escrita con el más fino pulso, con el juicio más maduro, y más acendrada crítica" 58 .

- "Nota del editor" para solidarizarse con el texto de la Real Cédula sobre la fundación de un Colegio de Misiones en Tarata, del 20 de noviembre de 1792, alabar al obispo de La Paz que lo promovió y elogiar a los misioneros que trabajarían con esas personas

56 Ibídem, t. XI, n. ${ }^{\circ} 357$ (5-VI-1794) 90. Texto en Biblioteca Nacional de España, hemeroteca digital: http://bdh.bne.es/bnesearch/hemeroteca/Correo\%20mercantil\%20de\%20 Espa\%C3\%B1a\%20y\%20sus\%20Indias, \%20El;jsessionid=71B29E7742C4964706EB A9AB26FBEF32.

57 Ibidem, t. XII, n. ${ }^{\circ} 589$ (sin fecha) 61-62.

58 Ibidem, t. XII, n. ${ }^{\circ} 595$ (sin fecha) 108-111. 
"enseñándoles a ser hombres, para después hacerlos cristianos". Luego hace un duro ataque a Francia (sin nombrarla), que acusa a España de los abusos cometidos en la colonización:

Corramos el velo a tan funestos atentados, notorios hoy a todo el mundo y obremos en silencio por la gloria de Dios: hagamos conocer su santo Nombre. Prediquemos la verdadera humanidad: formemos hombres mientras ellos van formando fieras, y entre tanto compadezcamos su ceguedad, lamentémonos de su triste suerte, y perdonemos sus calumnias ${ }^{59}$.

En la primera junta de la Sociedad editora del periódico, a comienzos de 1794, el director don Ambrosio Cerdán y Pontero, con motivo de la publicación de los estatutos de la entidad, recuerda los orígenes y hace una evaluación de lo hecho en el periódico por los miembros. Como signo del cambio notable que se da a la publicación está el hecho de fijar el número y clases de socios, buscar una sede permanente para reuniones y el trabajo de los miembros, y en cumplimiento de los estatutos — números XVI y XIX - se publicó un avance de contenidos que se tratarían en el futuro, divididos por materias y con el nombre de algunos de los miembros que los tratarían. Sin duda era un plan intelectual ambicioso que califica muy positivamente los ideales de este grupo de ilustrados peruanos ${ }^{60}$.

En ese programa se habla del trabajo asignado al P. fray Diego: "habiéndose encargado recientemente de escribir sobre la Población antigua y moderna del Perú, y sobre el punto contenido en el núm. 73 de Plan de materias ya puntualizado" ${ }^{61}$. Ese punto estaba dentro de la sección de bellas artes, y tenía como epígrafe un tema interesante: "Diversos rasgos sobre Bellas Artes y su estado actual en Lima". Por el desarrollo negativo de los acontecimientos sobre el periódico, no hubo tiempo para que el padre jerónimo desarrollase el tema y tuvo que emplearse activamente en la gestión publicando las notas a las que más arriba hemos hecho referencia.

59 Ibídem, t. XII, n. ${ }^{\circ} 605$ (sin fecha) 191-192.

60 Ibídem, t. X, n. 331 (6-III-1794) 152-158.

61 Ibídem, t. X, n. ${ }^{\circ} 332$ (9-III-1794) 161.

Bol. Acad. peru. leng. 54(54), 2012 
Cuando los gastos de la edición fueron mayores que lo ingresos por la reducción del número de suscriptores y el déficit se mantuvo, no hubo más remedio que liquidar el periódico. Fruto del amor y de la entrega a la Sociedad de Amantes del País y de su responsabilidad como redactor y miembro del equipo directivo, el P. Cisneros tuvo un gesto de su categoría humana e intelectual: reunió los trabajos recogidos para publicarlos con su dinero particular en futuros números; así se editó el tomo XII, último del Mercurio ${ }^{62}$.

J. P. Clément apunta causas económicas, pero antepone otros motivos como factores determinantes para el fin del Mercurio: la baja en la calidad que ocasionó la pérdida de suscriptores, el tratarse de un órgano de ilustrados que defendían los principios de aquel movimiento, los secuestros de algunos números y el caso Baquíjano (Clément 1997. T. I: 61-69, 261-266).

Pese a que las crisis de cualquier empresa nunca se deben al fallo de un factor sino a un conjunto de ellos, creemos que hay que volver a priorizar los asuntos económicos como causa determinante, que es la que adujeron los propios miembros de la Sociedad de Amantes del País, como veremos a continuación. Recientemente, el profesor Guibovich (2005: 63-65) ha expuesto documentación bastante evidente ${ }^{63}$ al respecto; también hemos visto la opinión del virrey Gil de Taboada, líneas más arriba.

Que la calidad bajara es cosa cierta, pero solo parcialmente, porque quizás fuese el gusto de los suscriptores por ver publicados otros temas lo que motivó las críticas y la reducción del número de suscripciones; los cambios de texto en los números 50 y 348 están explicados en las respectivas —aunque sean justificaciones diplomáticas para evitar

62 Así lo indica el propio virrey Taboada que reunió la crónica de los sucesos que llevaron a ese fin. MEDINA 1904-1907. T. III: 222-224; T. IV: 35.

63 La relación del manuscrito de autor anónimo de la Duke University que cita debemos recogerla y anotarla como un dato más, pero hay suficiente documentación contrastada de la época. 
mayores escándalos- ${ }^{64}$; tanto el tema de Baquíjano como la denuncia a la Inquisición del P. Cisneros y el secuestro de parte de su biblioteca privada habían sucedido muchos años antes de existir el Mercurio, y no pudo tener efectos retroactivos que influyesen en el fin.

La introducción al tomo XI es un texto bastante claro en el cual se detalla con precisión y claridad el asunto; el P. Cisneros como secretario de la Sociedad de Amantes del País explica la situación al público en nombre de la entidad. Aun aceptando que la calidad de los artículos hubiese decaído al igual que el interés del público en los temas tratados ${ }^{65}$, se debe reconocer que los motivos para cerrar el Mercurio eran fundamentalmente económicos:

Gracias al zelo y eficacia del Señor Presidente, que en medio de sus tareas ordinarias ha sabido vencer los obstáculos, no menos con su genial moderación que con sus sabias producciones.

Los demás Socios a su exemplo prosiguen trabajando con los mejores deseos de complacer al Público; pero este se ha entibiado mucho en el fomento de tan importante obra. Tal vez dirá el Público que más se ha entibiado la Sociedad, y quizás no le falta razón; pero seamos todos equitativos. La Sociedad deseara publicar con frequencia algunos suplementos agradables además del pliego que contiene el Mercurio; mas équé haremos quando después de algunas exhibiciones voluntarias que han ofrecido los Socios, no alcanza todavía el producto de las subscripciones para los gastos ordinarios de la Prensa, y Repartidores? Es menester a la verdad mucha constancia y zelo del bien general para proseguir una Obra Periódica, todos los Jueves y Domingos, en medio de tantas escaseces. Estas

64 No hemos visto nada respecto a los números 43, 216, 303 y 304 sobre los que hablan Clément y el autor anónimo del manuscrito de Duke University.

65 Los mismos miembros del equipo de redacción reconocen cierta baja de calidad en la introducción/editorial al tomo VII: "A pesar de todos estos agradables inciensos [las cosas buenas que ha enumerado], conocemos y confesamos que en estos últimos tiempos el Mercurio ha descaecido mucho de su valor primitivo. Todos los rasgos impresos en este postrer quatrimestre, y aun muchos de los del penúltimo son agenos", t. VII, n. ${ }^{\circ} 210$ (6-I1793) 17. También hace referencia a ella el virrey Gil de Taboada en su Relación: "A pesar de estas conocidas ventajas [los aspectos buenos], lo noté abandonado, y por tanto pasé oficio a la Sociedad para que me expusiese las causas de su acabamiento", Real Academia de la Historia, 9/1707. 
impiden también el que la Sociedad de a sus algunos particulares mapas del Reyno que desea comunicar al Público, a quien hacen notable falta. En doscientos años no se ha publicado un buen mapa del Reyno del Perú, y se han estampillado millares, todos defectuosos. Por esto es nuestra intención luego que haya fondos dar a luz los que se nos presenten de las varias Provincias de este dilatado imperio... ${ }^{66}$.

Este texto en el que se expresa la angustiosa situación económica se está escribiendo cuatro meses antes de cerrarse el periódico, lo que significa que la Sociedad hizo un último esfuerzo, económico y de ilusión, por mantener el Mercurio.

La razón económica es la que aduce don Hipólito Unanue al virrey Gil de Taboada cuando el 15 de octubre de 1794 le informa de la supresión del periódico:

Vuestra Excelencia, sumamente interesado en evitar su ruina, pasó inmediatamente oficio a la Sociedad para que esta le expusiese las causas que habían interrumpido la publicación de aquel periódico. La Sociedad hizo presente a Vuestra Excelencia la falta de fondos, suplicando se dignase asignarla cuatrocientos pesos que antes se daban de orden de Su Magestad al doctor don Cosme Bueno, para que costease un amanuense que le llevase la pluma en la descripción geográfica del reino, de que estaba encargado; $[. .$.$] y que al mismo tiempo se reuniese otro subsidio,$ que unido al primero, coadyuvase a los gastos del Mercurio ${ }^{67}$.

66 Mercurio Peruano, t. XI, n. ${ }^{\circ} 347$ (1-V-1794) 1-2. Es de notar que, junto a la cuestión económica, el otro factor que destaca es la esclavitud que suponía para los redactores tener que preparar la publicación de dos números semanales, teniendo en cuenta que todos estaban ocupados en otros trabajos personales fundamentales.

67 Texto citado en ARIAS-SCHREIBER (1974: 552). El mismo argumento es el que recoge el virrey en su memoria (MEDINA 1904-1907. T. III: 223). Cuando don Manuel Godoy creó los Estudios Superiores de Medicina solicitó a don Francisco Gil de Taboada que le enviara textos científicos impresos para la biblioteca enterado de que en el Mercurio se habían publicado trabajos de esta índole; el virrey le responde que no puede hacerlo "por haber cesado su impresión a causa de que sus autores no sacaban para los gastos que en ello impedían". Texto citado en LOHMANN y VILLANUEVA (1972. T. XXII: 84). 
Posiblemente con el virrey anterior, conde de Croix, las cosas hubieran sido muy distintas por la estrecha relación que mantenía con el padre jerónimo, pero eran otros años y otra situación. Es fundamental mirar la situación de Europa en esos momentos y la deriva de la Revolución francesa instalada en la fase del "terror" que estaba sobrecogiendo a las monarquías del viejo continente convencidas de que la expansión de las ideas que la provocaron era la explicación intelectual de los acontecimientos.

\section{Un sambenito peor que los del Santo Oficio}

Basados en una suposición, sin pruebas, al P. Diego Cisneros se le acusó de ser uno de los máximos responsables de que ingresaran a Lima libros prohibidos durante decenios. Como ejemplo de lo que decíamos al comienzo, vamos a recoger una antología de testimonios de los autores que han hablado del P. Cisneros y su relación con los libros prohibidos, siguiendo las primeras insuficientemente documentadas.

Respecto a la solución del virrey Gil de Taboada, cuenta J. T. Medina que Cisneros tenía obras prohibidas de Voltaire en su poder, las cuales le fueron confiscadas con otras - cincuenta y nueve en total- después de la denuncia formulada contra el jerónimo por el padre del Oratorio, Juan Rico. Afirma, también, que Cisneros había logrado obtener esas obras por ser la persona que nombró el virrey como delegado gubernamental para el examen de los libros que llegaban a Lima (Medina 1904-1907. T. I: XCVII $)^{68}$.

Posteriormente esa opinión fue desarrollada por Mendiburu ${ }^{69} \longrightarrow$ sin

68 Teniendo en cuenta que lo dice hablando del Virrey Gil de Taboada parece que fue este quien lo nombró visitador de Bibliotecas e inspector de los libros que llegaban, habiendo sido obra de su antecesor el conde de Croix, cfr. AGI, Lima, 674, N. 32. Se confunde J. P. Clément (1977. T. I: 266) cuando también atribuye el nombramiento al virrey Gil de Taboada, tomando la referencia de Medina.

69 “(...) y por las recomendaciones que le favorecieron [al P. Cisneros], creemos que en sus cajones de volúmenes impresos, se librarían del riguroso escrutinio que en la aduana se practicaba... Es de suponer que los dichos libros [los que primeramente facilitó Cisneros a Rodríguez de Mendoza] serían prohibidos, desde que no se vendían públicamente,

Bol. Acad. peru. leng. 54(54), 2012 
aportar ninguna clase de documentos, los cuales serán difíciles de encontrar-, quedando como referencia para los historiadores que en la tienda del Nuevo Rezado había un trasiego de obras no litúrgicas que el padre jerónimo, como traficante de libros prohibidos, vendía en la clandestinidad. Esa es la idea que a lo largo del pasado fueron repitiendo prestigiosos autores como J. G. Leguía ${ }^{70}$, J. María García Escudero ${ }^{71}$, E. D. Tovar ${ }^{72}$, L. A. Eguiguren ${ }^{73}$, V. A. Belaunde ${ }^{74}$, R. Contreras $^{75}$, C. Milla Batres ${ }^{76}$,

con lo que se prueba lo que antes hemos dicho sobre el pase de ellos por la aduana sin reconocimiento ni examen, tal vez en el concepto de que fuesen misales y breviarios" (MENDIBURU 1932: 161).

70 Cita en este aspecto la primera edición del Diccionario de Mendiburu (1932. T. II: 379). Véase LEGUÍA 1922: 27.

71 "En Perú, conviene añadir, el propio virrey D. Teodoro de Croix era el primer liberal y amigo de las 'luces'. Llegaban libros prohibidos a fray Diego Cisneros, ex confesor de la Reina María Luisa, que luego los repartía contribuyendo así al influjo de las nuevas ideas" (GARCÍA 1943, nota 8). Se publicó en la sección titulada "Mundo Hispánico".

72 "Fray Diego Cisneros se encargó de la peligrosa tarea de introducir clandestinamente en el Perú las obras de los enciclopedistas" (TOVAR 1946: 154). Ya en este siglo XXI el profesor Fabián Novak Talavera (2005: 25-26), daba una visión romántica de las reuniones ilustradas en casa de Cisneros o de Rodríguez de Mendoza, citando la opinión de E. D. Tovar.

73 "El padre Cisneros gozaba del prestigio de su saber, del apoyo que le prestaba el Virrey Croix (...). En la calle Padre Jerónimo, que lleva ese nombre en recuerdo de Fray Diego Cisneros, este tenía una librería donde se vendían libros que pasaban por la aduana, libres de toda investigación. El padre Cisneros, por eso, podía fácilmente suministrar a sus amigos sanmarquinos Bermudes, Arris, Rodríguez de Mendoza, etc. volúmenes prohibidos" (1950: 135).

74 También este autor responsabiliza a Cisneros de la llegada de libros prohibidos, pero no a través de su oficio de inspector, sino en su faceta de administrador del Nuevo Rezado: "El más interesante y típico ejemplo de contrabando de estos libros es el caso de Fray Diego Cisneros. Aprovechándose de los privilegios que le daba el comercio de misales, breviarios y libros de devociones, el famoso padre jerónimo introdujo en Lima una basta biblioteca que fue aprovechada por los redactores del Mercurio Peruano y por sus amigos y protegidos" (1959: 47). Repite la cita textual ROJAS 2002: 25.

75 Habla de la supuesta influencia de Cisneros para esa actuación: "Era famosa la librería del P. Diego de Cisneros, gran amigo de Toribio Rodríguez de Mendoza (...). Cisneros importaba libros que, gracias a sus influencias, pasaban libres de la investigación aduanera" (1982: 111).

76 "Además de los libros que públicamente exhibía, fue introduciendo en la capital del virreinato los impresos prohibidos por la censura (...). Acudieron a frecuentarlo los intelectuales ansiosos de conseguir los libros que contenían las novedosas ideas de la ilustración" (1986, T. I: 395). 
F. Romero ${ }^{77}$, R. Porras ${ }^{78}$, J. P. Clément ${ }^{79}$, etc.

Repetimos el razonamiento expuesto en nuestro anterior trabajo ${ }^{80}$ : que en los cajones del Nuevo Rezado entrasen libros prohibidos junto a los litúrgicos para soslayar los controles aduaneros de la Inquisición que sin duda serían más benévolos en el escrutinio con los que llegaban con estos productos, era posible, pero no probable, sobre todo en el volumen que cifran los autores antes mencionados; por lo tanto, creemos que hacer a fray Diego responsable directo de la entrada de libros prohibidos en Lima puede ser arriesgado, por erróneo, si no hay respaldo documental que lo pruebe $^{81}$. Una actividad de esas características suponía tener contactos fiables y seguros en Cádiz, que era donde se preparaba definitivamente el envío para introducir en los cajones las obras prohibidas junto a los libros litúrgicos que mandaban desde la administración general del Nuevo Rezado de Madrid. Muchas manos, muchos ojos, como para que las lenguas no hablasen y se difundiese la noticia, y más entre religiosos y seglares trabajando para eclesiásticos, donde lo privado se hace público y lo secreto se pregona a los cuatro vientos. Operación verosímil una vez, pero peligrosa si se realizó en varios envíos, que es lo que afirman los autores antes citados ${ }^{82}$.

77 "Este virrey [don T. de Croix], quien no podía ignorar que D. Diego era el mayor contrabandista de libros prohibidos (...)" (1973: 171).

78 Habla Milla Batres: "Cisneros [anota Porras], ejerciendo 'el honroso contrabando de los libros prohibidos', formaría a varios de los que luego serían ideólogos de la independencia” (1986. T. I).

79 "El jerónimo fue juzgado más tarde por la Inquisición por poseer obras de Voltaire, iprobablemente sustraídas durante los controles que él estaba encargado de realizar!" (1997. T. I: 266).

80 CAMPOS 2009a: 217-218.

81 Sabemos que, desde 1784, Cisneros junto a los comisionados por el Tribunal efectuaban los reconocimientos a los cajones de libros que llegaban. AGI, Lima, 1000; cfr. Lima, 674, N. 2.

82 Mendiburu apunta una idea que no hemos visto en ninguna otra parte, hasta hace poco, y no deja de sorprendernos. Asegura que: "Cisneros no solo organizó el comercio mercantil de libros [del Nuevo Rezado], sino que abrió tienda pública en la calle del Pozuelo, vendiendo en ella otras obras en virtud del permiso que tenía" (1932. T. IV: 161). De ahí la toma el profesor J. P. Clément (1997. T. I: 33).

Bol. Acad. peru. leng. 54(54), 2012 
Otra cosa es que al P. Cisneros le llegaran en estos cajones libros para su uso particular (y tenemos constancia de ello), pero eran envíos conocidos. En una ocasión le recuerda al P. Almagro que está esperando el curso de filosofía del P. Celis que había visto en la gaceta y lo debió de pedir ${ }^{83}$. En otra carta le recuerda al mismo Almagro que el P. Arredondo, que fue prior de Montserrat — probablemente en Madrid—, había dejado unos libros para él en el Cuarto de Madrid; le pide que se informase, por favor, para enviarlos a Cádiz si no lo habían hecho ya ${ }^{84}$. Y fray Diego, hombre culto y de libros, los tuvo en Lima, llegando a formar una buena biblioteca privada. En esta había algunos textos prohibidos, pero los guardaba con discreción, tras el escándalo ocasionado por el clérigo Juan Rico que decide denunciarlo a la Inquisición "en descargo de la conciencia" (que era el motivo que tapaba mucha deformación de mente y de espíritu). Rico afirma que una de las veces que fue a visitar a Cisneros "dicho padre señalándole con dedo al declarante, como cincuenta volúmenes de libros en lo alto de un estante, le dijo que era la obra de Voltaire, y añadió haber leído algo de ella (...)"

Sin duda en la casa particular de Cisneros de la calle de Santa Teresa y en torno a esa biblioteca privada tuvo que haber tertulias de amigos, como las hubo en otras casas de la sociedad ilustrada limeña; se puede admitir esta idea como tesis probable, pero ello no cambia la realidad ${ }^{86}$.

83 Lima, 2-IV-1789. Biblioteca Real del Escorial, LIII-151 (provisional). Ignoramos de quién se trata; conocemos al padre Camilo I. Pérez de Celis que, en 1793, publicó en Madrid Filosofía de las costumbres.

84 Lima, 20-VIII-1789. Biblioteca Real del Escorial, XXXVIII-54.

85 AHNM. Inquisición, leg. 2214, exp. 24. MEDINA 1956, T. II: 831; por error se le denomina al comienzo Fr. Diego de Cisternas.

86 "Los redactores de Mercurio Peruano vivían absortos con las ideas del enciclopedismo. Desde luego, la biblioteca del Padre Diego Cisneros, ya entonces sospechosa de herejías y por lo mismo doblemente atractiva, constituía uno de los centros de los sabios señores. No es de extrañar que andando el tiempo, y no mucho, al faltar el apoyo virreinal a causa de suspicacias despertadas por las audaces ideas de los "mercuriales", surgió espontánea, pero fugaz, la cooperación económica del Padre Cisneros, el famoso 'Padre Gerónimo' que dio nombre a la calle de Santa Teresa (hoy cuarta del Jirón Puno) donde vivía y tenía sus libros". SÁNCHEZ, L. A. (1964); publicado también, junto a otros trabajos, con ocasión de presentarse la edición facsímil del periódico. Versión digital: www.bvirtual.bnp.gob.pe/ BVIC/Captura/.../043_044_boletin_bnp.pdf, p. 21; CAMPOS 2009a: 189-190. 
El 15 de diciembre de 1786 el secretario del Santo Oficio, Miguel Manuel de Arrieta, confirma "la diligencia que se le encargó para recogerle al Padre Fray Diego Cisneros, del Orden de San Gerónimo, algunas obras prohibidas que había noticia tenía en su poder" ${ }^{87}$. Es extraño que el registro y la requisa solo se efectúasen en la vivienda particular de la casa donde moraba el P. Cisneros, ubicada en la calle de Santa Teresa —antes de Juan Valiente y del Estanco Viejo- - sin incluir la tienda y el depósito del Nuevo Rezado, donde presumiblemente debían de estar los libros prohibidos que supuestamente traía para vender a sus amigos, hecho del cual no se habla en el proceso; pero lo que resulta más evidente es que no se le acusa de vendedor/distribuidor de libros prohibidos. Si los miembros del Santo Oficio tenían ganas de echarle mano, también es extraño que después de finalizado el mandato de su amigo el virrey Croix (1790), no hubieran buscado excusas o motivos para realizarr un nuevo registro.

Por último hay que recordar que en la inspección de libros que se hacía en la aduana estaban presentes familiares del tribunal, con lo que resultaba bastante temerario enviar libros prohibidos por el riesgo de que fuesen descubiertos, aunque viniesen en los cajones consignados como Nuevo Rezado, teniendo en cuenta que el destinatario, P. Cisneros, había sido denunciado. Además, la Inquisición no solamente no renunciaba a realizar la revisión de los envíos de libros que llegaban, sino que reclamaba la exclusividad de la inspección para los temas relacionados con la fe y las costumbres.

En el Consejo, a 17 de diciembre de 1787. Su Ilma. y Sres. Enríquez, Jiménez, Villena y Poveda. Escríbase al Tribunal de Lima que el Consejo ha notado haya dado lugar a que el Virrey se haya precisado a mandar recoger tantos libros prohibidos como supone en su edicto, como en aquella ciudad y Reino, y a tomar providencias para evitar su introducción. Que parece bien al Consejo lo que se ha acordado de reconocer en la Aduana los cajones de libros por los comisionados del Santo Oficio y que supone que el comisionado por el Virrey [P. Cisneros] solo deberá conocer de los prohibidos por el Estado o Gobierno, y no por el Santo Oficio,

87 Archivo Histórico Nacional (Madrid), Inquisición, leg. 2214, exp. 24.

Bol. Acad. peru. leng. 54(54), 2012 
los que no puede ni debe retener, y cuyo conocimiento le es privativo al Tribunal (...). Enero $1788^{88}$.

Seguimos pensando que hay que restar protagonismo al P. Diego Cisneros en lo referente al ingreso de libros prohibidos en Lima, hecho que le han atribuido los historiadores.

Posteriormente y por propia confesión del padre jerónimo, descubriremos que, como prueba de gran afecto hacia la Universidad de San Marcos que con tanto cariño le había recibido como bibliotecario, le donó sus libros particulares. En el recurso que eleva al Superior Gobierno, el 11-V-1808, quejándose del estado de abandono en que estaba la librería universitaria y pidiendo que se aplicasen las disposiciones dadas para su reforma, afirma que "no solo ha ocupado en la referida época el servicio de algunos dependientes, y aún de su misma persona, sino que ha contribuido con un crecido número de sus obras para integrar los notables vacíos que sufrían muchos ramos de la mejor literatura" ${ }^{89}$. No hay noticia de que entre los libros del P. Cisneros que ingresaron en la biblioteca universitaria hubiese algunos prohibidos; además, alguien del personal podría haberlo denunciado si hubiera llegado a percatarse de este suceso. Es casi seguro que la biblioteca del padre jerónimo fue donada íntegramente a la universidad porque en el inventario que se hizo post mórtem se señalan papeles pero no se menciona la existencia de libros $^{90}$. Cuando se fundó la Biblioteca Nacional de Lima, se ordenó que

88 Archivo Histórico Nacional (Madrid), Inquisición, leg. 2214, exp. 25.

89 "Expediente sobre la provisión del cargo de Bibliotecario en la Real Universidad de San Marcos". Biblioteca Nacional del Perú, Fondo Antiguo, D 159. El documento fue deteriorado por el fuego. C. A. Romero lo transcribió antes del incendio de la Biblioteca; luego publicó un resumen en Boletín Bibliográfico de la Biblioteca Central de la Universidad Mayor de San Marcos, p. 41; SANTILLÁN. "Apuntes para la Historia de la Biblioteca Central de la Universidad de San Marcos: Derrotero de una antigua ilusión”, p. 5. Versión digital en: www.documentalistas.com//web/biblios/articulos/2B2-02.pdf.; "Bibliotecas peruanas del siglo XVIII" (MACERA 1977: 124-137) (también publicado en MACERA 1977: 300-301); ROMERO, F. 1973: 172; MILLA 1986. T. I: 396.

90 "Razón de los expedientes y demás papeles que se encontraron en el Estudio del finado R.P.M. Fr. Diego Cisneros (...) y constan por los 3 legajos”. Archivo Histórico de la Nación (Lima), Asuntos Eclesiásticos, leg. 34.43. 
los libros de la universidad pasasen a engrosar los fondos de la primera librería del país ${ }^{91}$.

A finales de esa centuria, el virrey Gil de Taboada y Lemus informa a su sucesor de los medios de los que ha dispuesto para controlar la penetración de los escritos revolucionarios y la de posibles agentes de Francia. El Virrey pensaba que su método era eficaz; sin embargo, los libros ingresaban y no por vía del padre jerónimo:

deputé para esto [control] sujetos que observasen las expresiones vertidas en las concurrencias públicas y secretas; y luego que llegó a mi noticia haberse esparcido por el Nuevo Reino de Granada un papel seductivo titulado los "Derechos del Hombre", se dictaron las providencias correspondientes a impedir su traslación. Mandé también practicar semejantes indagaciones sobre el número de todos los europeos que habían pasado a esta América desde el año 1790 hasta el presente, con especificación de sus nombres, patria y destino, verificándose iguales exámenes con los que llegaban a bordo de las embarcaciones procedentes de los puertos de la península, y otros de este hemisferio. Y bastando por todo lo que se trabajó la causa respectiva a varios franceses libertinos y que se ha relacionado en las que se comprenden en el [apartado] Estado de Justicia, se acredita que la tranquilidad, y sosiego de esta parte de la América, se ha debido a la justa inspección de mis connatos en el dócil y fiel ánimo de estos moradores ${ }^{92}$.

91 "En opinión de algunos autores, el fondo inicial de la Biblioteca Nacional tuvo como base la colección que donara San Martín, otros afirman que fue la biblioteca privada del padre Fray Diego Cisneros la que constituyó el más importante contingente de libros con el que se contó en la naciente biblioteca. Al crearse la Biblioteca Nacional, el fondo ascendió a 11.256...", PADRÓ y TAMAYO (1992: 344); MENDIBURU (1932. T. IV: 166).

92 Relación de gobierno del Excmo. Señor Virrey del Perú, Frey Don Francisco Gil de Taboada y Lemus. Año de 1796. Real Academia de la Historia, 9/1707, ff. 82v-83. Sin duda se refiere a la traducción y edición clandestina completa que hizo el prócer colombiano Antonio Nariño en Bogotá, en 1793. Por esto fue hecho prisionero el 29 de agosto de 1794, en el cuartel de caballería de Santafé por orden del oidor Joaquín Mosquera, juez comisionado para instruir el proceso. RUIZ 1991. Texto en Biblioteca Virtual del Banco de la República (Colombia): http://www.banrepcultural.org/blaavirtual/revistas/credencial/julio1991/ julio1.htm 
Para finalizar este nuevo trabajo sobre el padre Cisneros que nos ha permitido iluminar algo más su vida, nos valemos del elogio que le dedicó F. Romero en su apunte biográfico: "Se ha dicho que el hombre sólo es de donde ama. La patria es cariño a la tierra en que se vive y comunión espiritual con quienes la habitan. Esto tuvo en grado apreciable D. Diego, y es lo que debemos agradecerle" (1973: 172). 


\section{BIBLIOGRAFÍA}

\section{ABATE TIRON}

1851

Historia y trajes de las órdenes religiosas. Tomo II. Barcelona.

ANÓNIMO

1990

Las mil y una noches. Tomos 1 y 2 . Lima.

ARIAS-SCHREIBER PEZET, J. (comp.)

1974 Los ideólogos. Hipólito Unanue. Vol. 8. Lima.

ARZE, D. de

1888 (2012) De las librerías, de su antigüedad y provecho... Madrid. Edición facsimilar: Madrid.

BARRIGA CALLE, I.

2002 "El Mercurio Peruano y los muertos". En: GUERRA, M. et al. Sobre el Perú. Homenaje a José Agustín de la Puente Candamo. Tomo I. Lima.

BATAILLON, M.

1983 Erasmo y España. Madrid.

BELAUNDE, V. A.

1959 Bolivar y el pensamiento de la revolución hispanoamericana. Madrid.

\section{BLÁZQUEZ, J.}

1986 La Inquisición en Castilla-La Mancha. Córdoba.

BORGES, Jorge Luis

1985 "La biblioteca de mi padre". En: El Correo de la Unesco. Madrid, febrero.

BROMLEY, J.

2005 Las viejas calles de Lima. Lima, n. 215.

Bol. Acad. peru. leng. 54(54), 2012 
CALERO Y MOREIRA, Jacinto

1790 Prospecto de papel periódico intitulado Mercurio Peruano de Historia, Literatura, y Noticias públicas, que a nombre de una Sociedad de Amantes del País, y como uno de ellos promete dar a luz. Lima.

CAMPOS, J.

1993

"La Corte y la Comunidad en las 'jornadas' anuales del Real Sitio de San Lorenzo". En: La música en el Monasterio del Escorial. Actas del Simposium. San Lorenzo del Escorial.

1998 "Felipe II, el monasterio del Escorial y el Nuevo Rezado (1573-1598)". En: Felipe II y su época. Tomo II. Actas del Simposium. San Lorenzo del Escorial.

2007 "El monasterio de San Lorenzo el Real en la época del 'Proceso del Escorial', 1807-1808”. En: Cuadernos de Pensamiento (Madrid), 19, 269-313.

2008 "Los reyes de España y la orden de San Jerónimo en los siglos XV-XVI". En: Carlos V en Yuste. Muerte y gloria eterna. Catálogo de la exposición, Monasterio de Yuste, 2008. Madrid.

2009a "Del Escorial a Lima: Fray Diego Cisneros, bibliotecario e ilustrado". En: Boletín de la Real Academia de la Historia (Madrid), 206 / 2, 177-229.

2009b "El monje jerónimo español fray Diego Cisneros, el Santo Oficio de Lima y el Inquisidor General". En: Anuario Jurídico y Económico Escurialense (San Lorenzo del Escorial), 42, 522-530.

2010 Arias Montano en la Biblioteca Real y en el Gabinete de Estampas del Escorial. San Lorenzo del Escorial. 
[En prensa] "El padre jerónimo Diego Cisneros, los libros prohibidos y el Mercurio Peruano".

CASSAGNE, J. C.

2012 "El bicentenario de la Constitución de Cádiz y su proyección en Iberoamérica”. En: MARTÍ MINGARRO, L. (coord.). Cuando las Cortes de Cádiz. México.

CASTRO, A.

1970

Aspectos del vivir hispánico. Madrid.

CLÉMENT, J. P.

1979 Índices del Mercurio Peruano. 1790-1795. Lima.

1997 El Mercurio Peruano (1790-1795). Estudio y Antología. Tomo I. Frankfurt-Madrid.

CONTRERAS, R.

1982 Relación y documentos de gobierno del Virrey del Perú, Agustín de Jáuregui y Aldecoa (1780-1784). Madrid.

DEMERSON, Paula de; DEMERSON, J. y AGUILAR, P.

1974 Las Sociedades Económicas de Amigos del País en el siglo XVIII. Guía del Investigador. San Sebastián.

DOMINGO MALVADI, A.

2011 Bibliofilia Humanista en tiempos de Felipe II. La Biblioteca de Juan Páez de Castro. Salamanca.

EGUIGUREN, L. A.

1950 La Universidad Nacional Mayor de San Marcos. Lima.

ENCISO RECIO, L. M.

1957 Cuentas del "Mercurio" y la "Gaceta". Valladolid. 
1987 "Las Sociedades Económicas de Amigos del País". En: Historia de España, fundada por R. Menéndez Pidal y dirigida por José María Jover Zamora, vol. XXXI 1: La época de la Ilustración: el Estado y la Cultura. Madrid.

2010 Las Sociedades Económicas en el siglo de las Luces. Madrid.

\section{FERNÁNDEZ SARASOLA, I.}

$2000 \quad$ "La Constitución española de 1812 y su proyección europea e iberoamericana". En: Fundamentos. Cuadernos monográficos de teoría del Estado, derecho público e historia constitucional. (Oviedo), 2, 359-457.

FLÓREZ, G. C.

2002 "La Universidad de San Marcos y el Mercurio Peruano". En: Investigaciones Sociales (Lima), VI / 9, 107-117.

GÁLVEZ, J.

$1943 \quad$ Calles de Lima y meses del año. Lima.

GARCÍA ESCUDERO, José María

1943 "Un viraje en la interpretación de la Independencia Americana". En: Revista de Estudios Políticos (Madrid), 9-10, 473 , nota 8 .

GIL DE TABOADA Y LEMUS, Francisco

1707 Relación de gobierno del Excmo. Señor Virrey del Perú, Frey Don Francisco Gil de Taboada y Lemus. Año de 1796. Real Academia de la Historia, 9, ff. 85-87v.

GUIBOVICH PÉREZ, P. M.

2005 "Alcances y límites de un proyecto ilustrado: la Sociedad de Amantes del País y el Mercurio Peruano". En: Histórica (Lima), XXIX.2, 45- 66. 


\section{HAMPE MARTÍNEZ, T.}

1991 "La Revolución Francesa vista por el Mercurio Peruano: cambio político vs. Reformismo criollo". En: Les révolutions ibériques et ibero-américaines à l'aube du XIXe siècle. París.

IRIARTE, J. de

Regiae Bibliothecae Matritensis Codices Graeci: Mss. Vol. prius. Matriti. Anno MDCCLXIX.

LEGUÍA, J. G.

1922 El precursor. Ensayo biográfico de D. Toribio Rodríguez de Mendoza. Lima.

LEQUANDA, J. I. de

1794 "Discurso sobre el destino que debe darse a la gente Vaga que tiene Lima". En: Mercurio Peruano. Tomo X, n. ${ }^{0} 325$ (13-II-1794), 103-108; 326 (16-II-1794) 111-117; 327 (20-II-1794), 119-125 y 328 (23-II-1794), 127-132.

LINAGE CONDE, A.

2008 La vida cotidiana de los monjes de la Edad Media. Madrid.

LOHMANN, E. y VILLANUEVA, O. (comps.)

1972 Documentación oficial española: Gobierno virreinal del Cuzco. Colección Documental de la Independencia del Perú. Tomo XXII, Vol. I. Lima.

LÓPEZ SORIA, J. I.

1972 Ideología económica del Mercurio Peruano. Lima.

MACERA, Pablo

1962 "Bibliotecas peruanas del siglo XVIII". En: Boletín Bibliográfico de la Biblioteca Central de la Universidad Mayor de San Marcos. (Lima), XXXIII/3-4, 124-137. 
1977 Trabajos de Historia. Vol. I. Lima.

MALVADI A., Domingo

2011 Bibliofilia bumanista en tiempos de Felipe II. La biblioteca de Juan Páez de Castro. Salamanca.

MARIÁTEGUI, J.

1994 El Mercurio Peruano y la medicina. Lima.

MEDIAVILLA, B.

2009 Libro de Cuentas del Real Monasterio del Escorial. San Lorenzo del Escorial.

2010 Inventario de Documentos. Real Biblioteca del Escorial (15601885): 2. ${ }^{a}$ parte. San Lorenzo del Escorial.

MEDINA, José Toribio

1904-1907 La Imprenta en Lima (1584-1824). Tomos I, III y IV. Santiago de Chile.

1956 Historia del Tribunal de la Inquisición de Lima (1569-1820). Tomo II. Santiago de Chile.

MENDIBURU, J. de

1932 Diccionario Histórico-Biográfico del Perú. Tomos II y IV. Lima.

Mercurio Peruano. Tomo I, n. ${ }^{\circ} 11$ (6-II-1791), 100-105.

. Tomo VI, n. ${ }^{\circ} 174$ (2-IX-1792), 1.

. Tomo VI, n. ${ }^{\circ} 174$ (2-IX-1792), 1-2.

. Tomo VII, n. ${ }^{\circ} 209$ (3-I-1793), 6.

. Tomo VII, n. ${ }^{\circ}$ s 209 y 210 (3 y 6-I-1793), 1-19.

. Tomo VII, n. ${ }^{\circ} 210$ (6-I-1793), 17.

. Tomo VII, n. ${ }^{\circ} 210$ (6-I-1793), 19-23.

. Tomo X, n. ${ }^{\circ} 329$ (27-II-1794), 135-142.

. Tomo X, n. ${ }^{\circ} 332$ (9-III-1794).

. Tomo XI, n. ${ }^{\circ} 347$ (1-V-1794), 1-2. 
. Tomo XI, n. 357 (5-VI-1794), 90.

MILLA BATRES, Carlos

1986 Diccionario Histórico y Biográfico del Perú, siglos XV-XX. Tomo I. Lima.

MIRÓ QUESADA, A.

1966 "Amistades de Humboldt en Lima". En: Veinte temas peruanos. Lima.

MORÁN RAMOS, L. D.

2008 Reformistas, fidelistas y contrarrevolucionarios. Prensa, poder y discurso político en Lima durante las Cortes de Cádiz (18101814). Lima.

NIETO VÉLEZ, A.

1956-1957 "Notas sobre el pensamiento de la Ilustración en el Mercurio Peruano". En: Boletín del Instituto Riva Agüero (Lima), n. ${ }^{\circ} 3$.

NOVAK TALAVERA, Fabián

2005 Las relaciones entre Perú y Francia (1827-2004). Lima.

NÚÑEZ, E.

1936 "La versión alemana del Mercurio Peruano". En: Boletín Bibliográfico de la Biblioteca Central de la Universidad Mayor de San Marcos (Lima), IX / 1, 27-30.

1953 Autores germanos en el Perú. Lima.

1977 "El Mercurio Peruano", en PORRAS BARRENECHEA, R. y VARGAS UGARTE, R. Historia general de los peruanos. Lima, Año de los Censos Nacionales, vol. II.

2002

"Humboldt y el Mercurio Peruano", en NÚÑEZ, E. y PETERSEN, G. Alexander von Humboldt en el Perú. 
NÚÑEZ, E. y PETERSEN, G. G.

1971 "Prólogo" a El Perú en la obra de Alejandro Humboldt. Lima.

2002 Alexander von Humboldt en el Perú. Diario de viaje y otros escritos. Lima.

ÑQUE DE LA PUENTE, J. A.

2012 "Peruanos en la Corte de Cádiz”. En: MARTÍ MINGARRO, L. (coord.). Cuando las Cortes de Cádiz. México.

PADRÓ, G. y TAMAYO, J.

1992 "Biblioteca Nacional de Perú". En: Boletín ANABAD, XLII / 3-4, 344.

PALACIO ATARD, V.

1994 "La proyección Americana de la Real Sociedad Bascongada de Amigos del País". En: Factores de diferenciación e instancias integradoras en la experiencia del mundo Iberoamericano. II Congreso de Academias Iberoamericanas de la Historia. Madrid.

PERALTA RUIZ, Víctor

2006 "El Virrey Abascal y el espacio de poder en el Perú (18061916). Un balance historiográfico”. En: Revista de Indias (Madrid), LXVI / 236, 174.

PÉREZ DE URBEL, J.

1934 Los monjes españoles en la Edad Media. Tomo II. Madrid.

1970 Historia del Condado de Castilla. Tomo II. Madrid.

POUPENEY HART, C. (coord.)

2007a "El aporte de José Rossi y Rubí en el Mercurio Peruano". En: TINKUY. Boletín de investigación y debate (Université de Montréal), n. ${ }^{\circ}$ 6, 41-65. Número monográfico dedicado a la Serie Discursos Coloniales n. ${ }^{\circ} 1$. 
2007b "El Mercurio Peruano". En: TINKUY. Boletín de investigación y debate (Université de Montréal), n. ${ }^{\circ}$ 6, 25-40.

PUENTE BRUNKE, J. de la

2008 "El Mercurio peruano y la religión”. En: Anuario de la Historia de la Iglesia (Universidad de Navarra), 17, 137-148.

RATTO CHUECA, A.

1993 "Bibliografía de José Rossi y Rubí en el Mercurio Peruano". En: Lexis (Lima), XVII / 1, 143-152.

REY DE CASTRO, A.

2008 "El Mercurio Peruano y la formación de la conciencia nacional". En: El pensamiento político y la formación de la nacionalidad peruana (1780-1820). Lima.

RIVARA TUESTA, María Luisa

"Introducción" a Ideólogos de la Emancipación peruana. Versión digital: http://eltalondeaquiles.pucp.edu.pe/sites/eltalondeaquiles. pucp.edu.pe/files/ideologosdelaemancipacionperuana.pdf

ROJAS OSORIO, C.

2002 Latinoamérica, cien años de Filosofía. Vol. I. Isla Negra.

ROMERO, C. A.

1927

"La Biblioteca de la Universidad Mayor de San Marcos y el bibliotecario Fray Diego de Cisneros". En: Boletín Bibliográfico de la Biblioteca Central de la Universidad Mayor de San Marcos (Lima), III, n. ${ }^{\circ} 2$ (VI), 31-44.

ROMERO, F.

1973 Rodríguez de Mendoza: hombre de lucha. Lima.

RUIZ MARTÍNEZ, A.

1991 "Antonio Nariño: publicación clandestina de los Derechos del Hombre". En: Revista Credencial Historia (Bogotá), 
edición 19 de julio de 1991. Texto en Biblioteca Virtual del Banco de la República (Colombia): http://www. banrepcultural.org/blaavirtual/revistas/credencial/ julio1991/julio1.htm

SALAS OLIVARI, E.

1974 "Periódicos de la Pre-Emancipación. 1795-1819". En: Boletín de la Biblioteca Nacional de Perú, (Lima), 69-72, 5 y 7-9.

\section{SÁNCHEZ ALBORNOZ, C.}

1977 España, un enigma histórico. Tomo I. Barcelona.

SÁNCHEZ, L. A.

1964 "El Mercurio Peruano". En: Boletín Bibliográfico de la Biblioteca Central de la Universidad Nacional Mayor de San Marcos. (Lima), XXXVIII, n. ${ }^{\circ} 3$ y 4.

SANTILLÁN ALDANA, J.

"Apuntes para la Historia de la Biblioteca Central de la Universidad de San Marcos: Derrotero de una antigua ilusión". Lima.

TELLECHEA, J. I.

"La Real Sociedad Bascongada de los Amigos del País. Cien años de Investigaciones". En: http://www.euskomedia.org/ PDFAnlt/congresos/09/09217235.pdf

TOVAR, E. D.

1946 "Participación de Francia en el desenvolvimiento de la cultura peruana". En: Afinidades, Francia y América del Sur. Montevideo.

VARGAS UGARTE, R.

1961 Historia de la Iglesia en el Perú. Tomo IV. Burgos. 
1971 Historia general del Perú. Postrimerías del poder español (17761815). Lima.

\section{VARIOS}

1972

Las Reales Sociedades de Amigos del País y su obra. San Sebastián.

VEGAS VÉLEZ, M.

$1991 \quad$ Humboldt en el Perú. Piura.

VICUÑA MACKENNA, Benjamín

$1860 \quad$ La Independencia en el Perú de 1809 a 1819. Lima.

ZARCO, J.

$1924 \quad$ Catálogo de los manuscritos castellanos de la Real Biblioteca de El Escorial. Tomo I. Madrid.

1930 "Celdas y aposentos que han de servir al rey N.S. y A.A. con las demás comitiva en su Real Monasterio de San Lorenzo del Escorial". En: Los Jerónimos de San Lorenzo el real de El Escorial. San Lorenzo de El Escorial.

ZETA QUINDE, R.

2000 El pensamiento ilustrado en el Mercurio Peruano (17911794). Piura.

\section{ARCHIVOS HISTÓRICOS}

Archivo Histórico Nacional (Madrid), Inquisición, leg. 2214, exp. 24.

Archivo Histórico Nacional (Madrid), Inquisición, leg. 2214, exp. 25.

Biblioteca Nacional de España. Relación de los libros y papeles de la Secretaría de la Biblioteca Nacional que pasan a la Sección de Manuscritos de la misma en 1903. Madrid. BN-Archivo, 0133/04. Carta de 25-VIII-1769. 
Biblioteca Real del Escorial, XXXVIII-54.

Biblioteca Real del Escorial, ms. H.I.11, f. 107

Biblioteca Real del Escorial, ms. \&.II.15, ff. 190-195.

Biblioteca Real del Escorial, mss. Z.IV.21, ff. 39-49v, y Z.IV.23, ff. 335$345 \mathrm{v}$.

Biblioteca Real del Escorial: Lima, 20-VIII-1785 (XXVIII-54); 6-II1790 (XXIX-26/1); 16-X-1790 (XXXIX-26/2); 1790 (XXIX-26/3); 25-I-1792 (XXIX-42/1); 23-XII-1807.

Biblioteca Zabálburu, Madrid, doc. 80-192.

CODOIN. Vol. XLI, p. 408.

Concilios limenses. 3 vols. Lima, 1951-1954.

Elogio del Excelentísimo señor Don Agustín de Jáuregui, y Aldecoa; Caballero del Orden de Santiago, Teniente General de los Reales Ejércitos, Virrey, Gobernador, y capitán General de los Reynos del Perú, Chile, E, pronunciado en el recibimiento, que como a su Vice-Patrón, le hizo la Real Universidad de S. Marcos el día XXVII de Agosto del año de M.DCC.LXXXI, 4. ${ }^{\circ}, 82 \mathrm{pp}$.

"Expediente sobre la provisión del cargo de Bibliotecario en la Real Universidad de San Marcos". Biblioteca Nacional de Perú, Fondo Antiguo, D 159. El documento fue deteriorado por el fuego. C. A. Romero lo transcribió antes del incendio de la Biblioteca; luego publicó un resumen en Boletín Bibliográfico de la Biblioteca Central de la Universidad Mayor de San Marcos, a.c.; el texto citado, p. 41.

"Historia de la Sociedad Académica de Amantes del País, y principios del Mercurio Peruano", en Mercurio Peruano, tomo I, n. ${ }^{\circ} 7$ (23-I-1791), 49-50. 
Libro de los Actos Capitulares del Monasterio de San Lorenzo el Real. Tomo II.2, n. ${ }^{\circ}$ 611.2. San Lorenzo del Escorial, 2004.

Memorial autógrafo de Ambrosio de Morales sobre el orden de la Biblioteca del Escorial, ms. \&.II.15, f. 197.

"Razón de los expedientes y demás papeles que se encontraron en el Estudio del finado R.P.M. Fr. Diego Cisneros... y constan por los 3 legajos". Archivo Histórico de la Nación (Lima), Asuntos Eclesiásticos, leg. 34.43 .

\section{FUENTES CONSULTADAS EN INTERNET}

Hemeroteca Digital de la Biblioteca Nacional de España http:// bdh.bne.es/bnesearch/hemeroteca/Correo\%20mercantil\%20de $\% 20$ Espa\%C3\%B1a\%20y\%20sus\%20Indias, $\% 20 \mathrm{El}$;jsessionid $=71 \mathrm{~B} 29 \mathrm{E} 77$ 42C4964706EBA9AB26FBEF32

Museo de la Inquisición de Lima http://www.congreso.gob.pe/museo. htm (Inquisición $>$ Temas Inquisitoriales).

\section{Correspondencia:}

F. Javier Campos y Fernández de Sevilla

Profesor de Historia en los Estudios Superiores del Escorial de la Universidad Complutense.

Correo electrónico: jcampos@rcumariacristina.com 